\title{
Stable isotope records for the last 10000 years from Okshola cave (Fauske, northern Norway) and regional comparisons
}

\author{
H. Linge ${ }^{1,2}$, S.-E. Lauritzen ${ }^{1,5}$, C. Andersson ${ }^{2,1}$, J. K. Hansen ${ }^{1}$, R. Ø. Skoglund ${ }^{1}$, and H. S. Sundqvist ${ }^{3,4}$ \\ ${ }^{1}$ Department of Earth Science, University of Bergen, Allégaten 41, 5007 Bergen, Norway \\ ${ }^{2}$ Bjerknes Centre for Climate Research, Allégaten 55, 5007 Bergen, Norway \\ ${ }^{3}$ Department of Physical Geography and Quaternary Geology, Stockholm University, 10691 Stockholm, Sweden \\ ${ }^{4}$ Bert Bolin Centre for Climate Research, Stockholm University, 10691 Stockholm, Sweden \\ ${ }^{5}$ Department of Plant and Environmental Sciences, Norwegian University of Life Sciences, 1432 Ås, Norway
}

Received: 8 June 2009 - Published in Clim. Past Discuss.: 1 July 2009

Revised: 14 October 2009 - Accepted: 23 October 2009 - Published: 3 November 2009

\begin{abstract}
The sensitivity of terrestrial environments to past changes in heat transport is expected to be manifested in Holocene climate proxy records on millennial to seasonal timescales. Stalagmite formation in the Okshola cave near Fauske (northern Norway) began at about $10.4 \mathrm{ka}$, soon after the valley was deglaciated. Past monitoring of the cave and surface has revealed stable modern conditions with uniform drip rates, relative humidity and temperature. Stable isotope records from two stalagmites provide time-series spanning from c. $10380 \mathrm{yr}$ to AD 1997; a banded, multi-coloured stalagmite (Oks82) was formed between $10380 \mathrm{yr}$ and $5050 \mathrm{yr}$, whereas a pristine, white stalagmite (FM3) covers the period from $\sim 7500 \mathrm{yr}$ to the present. The stable oxygen isotope $\left(\delta^{18} \mathrm{O}_{\mathrm{c}}\right)$, stable carbon isotope $\left(\delta^{13} \mathrm{C}_{\mathrm{c}}\right)$, and growth rate records are interpreted as showing i) a negative correlation between cave/surface temperature and $\delta^{18} \mathrm{O}_{\mathrm{c}}$, ii) a positive correlation between wetness and $\delta^{13} \mathrm{C}_{\mathrm{c}}$, and iii) a positive correlation between temperature and growth rate. Following this, the data from Okshola show that the Holocene was characterised by high-variability climate in the early part, lowvariability climate in the middle part, and high-variability climate and shifts between two distinct modes in the late part.

A total of nine Scandinavian stalagmite $\delta^{18} \mathrm{O}_{\mathrm{c}}$ records of comparable dating precision are now available for parts or most of the Holocene. None of them show a clear Holocene thermal optimum, suggesting that they are influenced by annual mean temperature (cave temperature) rather than seasonal temperature. For the last 1000 years, $\delta^{18} \mathrm{O}_{\mathrm{c}}$ values display a depletion-enrichment-depletion pattern commonly interpreted as reflecting the conventional view on climate
\end{abstract}

development for the last millennium. Although the $\delta^{18} \mathrm{O}_{\mathrm{c}}$ records show similar patterns and amplitudes of change, the main challenges for utilising high-latitude stalagmites as palaeoclimate archives are i) the accuracy of the age models, ii) the ambiguity of the proxy signals, and iii) calibration with monitoring data.

\section{Introduction}

Scandinavia has mild weather conditions for its latitude because of the prevailing atmospheric and oceanic circulation patterns, and the oceanic summer heat storage (e.g. Drange et al., 2005). Alterations in the heat and moisture transport in the North-Atlantic and adjacent continents are largely explained by the North Atlantic Oscillation (NAO) (Hurrell et al., 2003). The sensitivity of terrestrial environments in northern Norway to changes in heat transport is largely unknown, however, changes in the past are expected to be manifested in Holocene climate proxy records on millennial to seasonal timescales. The success of modelling and forecasting of future climate depends on how well we understand the behaviour of the climate system, and we can only decipher its longer-term variability and natural modes of response by investigating climate proxy records. Furthermore, for meaningful temporal and spatial correlations of palaeoclimate reconstructions, we must be able to distinguish between true climate signals (e.g. regional persistence) and environmental signals (e.g. single archive occurrence), and to identify potential local factors that can bias the signal.

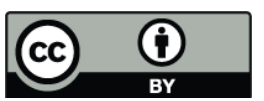

Correspondence to: $\mathrm{H}$. Linge (henriette.linge@geo.uib.no) 
Cave systems have variable suitability as palaeoclimate repositories. Here we present a well-dated stable isotope stratigraphy spanning the last 10000 years from two stalagmites from northern Norway that suggests that there is i) an apparent negative correlation between cave/surface temperature and stable oxygen isotopes, ii) a positive correlation between wetness and stable carbon isotopes, and iii) a positive correlation between cave/surface temperature and growth rate. Comparison with stalagmite records to the south (Lauritzen and Lundberg, 1999; Linge et al., 2001, 2009) and southeast (Sundqvist et al., 2007a, 2009) shows that although events can be correlated between the records, the main challenges for utilising high-latitude stalagmites as palaeoclimate archives are i) the accuracy of the age models, ii) the ambiguity of the proxy signals, and iii) calibration of proxies with monitoring data.

\section{Stalagmites as proxy archives}

Secondary calcium carbonate $\left(\mathrm{CaCO}_{3}\right)$ deposits in caves can be precisely and accurately dated by U-Th techniques (e.g. Ivanovich and Harmon, 1992; Richards and Dorale, 2003; van Calsteren and Thomas, 2006), and their existence is in itself a large-scale climate signal (e.g. Gascoyne, 1992). Although deposition can occur adjacent to or under glaciers in cases where and alternative mechanism (e.g. pyrite oxidation) generates high $\mathrm{P}_{\mathrm{CO}_{2}}$ seepage water (Atkinson, 1983; Spötl and Mangini, 2007), deposition is mainly possible during periods devoid of glaciers and permafrost at high latitudes/altitudes (e.g. Lauritzen, 1991, 1995). This is because precipitation of $\mathrm{CaCO}_{3}$ occurs when high $\mathrm{P}_{\mathrm{CO}_{2}}$ seepage water equilibrates with the cave atmosphere as the $\mathrm{CO}_{2}$ degasses to accommodate the lower- $\mathrm{P}_{\mathrm{CO}_{2}}$ atmosphere of the cave.. Stalagmites can thus conserve proxy archives of palaeoclimatic and palaeoenvironmental change (e.g. Gascoyne, 1992; Lauritzen, 2003; Fairchild et al., 2006). Stalagmite growth rate is related to regional climate through the cave temperature ( $\sim$ surface mean annual temperature), meteoric precipitation, soil activity and $\mathrm{Ca}^{2+}$ concentration in the drip water (e.g. Baker et al., 1998; Dreybrodt, 1999; Kaufmann and Dreybrodt, 2004). Fluctuations in growth rate can be used as a palaeoclimate proxy if site-specific, climaterelated controls on stalagmite formation can be identified. Growth rate has been used as a proxy for temperature (Genty et al., 2001), rainfall (Genty and Quinif, 1996) and vegetation (Baldini et al., 2005).

The stable isotope composition of stalagmite carbonate is a potential carrier of surface conditions (e.g. McDermott, 2004; Fairchild et al., 2006), and the oxygen isotope signal $\left(\delta^{18} \mathrm{O}_{\mathrm{c}}\right)$ has been the most widely used palaeoclimate proxy until now. By default, interpretation of stable isotope data from stalagmites depends largely on the climate zone they originate from. Deviations from equilibrium conditions may cause kinetic fractionation effects to dominate the sta- ble isotope composition (e.g. Mickler et al., 2006) and disturb its direct dependence on temperature. Although isotopic records often are acknowledged as palaeoclimatic records, the detailed control mechanisms for individual data points are rarely known, questioning the significance of variability observed in single stalagmite records. Linge et al. (2001) demonstrated inter- and intra-stalagmite variability in three records from a cave near Rana (northern Norway), illustrating that as palaeoclimate repositories stalagmites suffer from two main complications: 1) neighbouring stalagmites can be fed by dripwater flowing along very diverse (temporal, geochemical) percolation routes, hence producing weak inter-cave correspondence, and, 2) high-resolution sampling along one stalagmite growth axis may require dense dating to account for variability in temporal resolution if growth rate fluctuations are large/asynchronous.

For the Holocene in northern Norway, a negative relationship between $\delta^{18} \mathrm{O}_{\mathrm{c}}$ and annual mean temperature have been suggested for the near-coastal climate (Lauritzen and Lundberg, 1999; Linge et al., 2001), i.e. that increase in surface/cave temperature is recognised as $\delta^{18} \mathrm{O}_{c}$ depletion. Linge et al. (2009) showed that zones of condensed growth coincide with stable isotope enrichment and high luminescence ratios, suggesting that reduced rate of calcite accretion was caused by cooler conditions and reduced biological activity in the soil. In Europe, a negative relationship between surface/cave $\mathrm{T}$ and $\delta^{18} \mathrm{O}_{\mathrm{c}}$ is also reported for Holocene stalagmites from northwestern Sweden (Sundqvist et al., 2007a), and the Alps (e.g. Mangini et al., 2005; Vollweiler et al., 2006), whereas Sundqvist et al. (2009) discuss a potential shift from positive to negative relationship in a 4000-year long record from northwestern Sweden. Conversely, detrital layers and corrosional hiatuses in the $>350$ ka LP-6 (Lauritzen et al., 1990) showed strong $\delta^{18} \mathrm{O}_{\mathrm{c}}$ depletions and were interpreted as representing cold and probably glacial intervals.

\section{Site and material}

\subsection{The cave}

The Okshola cave is situated in Fauske municipality $\left(67^{\circ} \mathrm{N}\right.$, $15^{\circ} \mathrm{E}$, Fig. 1a) where the present-day climate is characterised as maritime with relatively mild winters and cool summers. The mean annual precipitation is about $1000 \mathrm{~mm}$, peaking in September-December (1961-1990, stations: Sulitjelma, Fauske-Veten, Fauske, www.met.no). Snow cover commonly prevails from late October till late April/early May (Aune, 1993). The mean annual temperature is about $+3.2^{\circ} \mathrm{C}$ (1972-1986, station Fauske-Veten, 160 m a.s.l., www.met. no), and November through March usually have average monthly temperatures below $0^{\circ} \mathrm{C}$. The vegetation growth season spans from early May to early October (Aune, 1993). 
The vegetation above the cave is dominated by birch/spruce forest, heather and peat moss.

The cave (Fig. 1b, c) has about $11 \mathrm{~km}$ of mapped passages, a depth of about $250 \mathrm{~m}$, and features a sloping lab yrinth of phreatic passages developed within marble with numerous mica schist partings (Lauritzen, 1996). The main entrance is at $165 \mathrm{~m}$ a.s.l., and the cave is relatively rich in both detrital and calcite deposits (Lauritzen, 1995). New mapping by Skoglund (unpublished) describes important aspects of the physical setting of Okshola in general and Fata Morgana (FM) in particular (Fig. 1b, c). FM is one of the main galleries, situated 200-300 m northwest of the entrance and under a topographic height (Fig. 1c, e), and its northern extension is plugged by till.

The bedrock overlying the cave consists of foliated marble and mica schist. Bedrock exposures in the catchment area are rare other than in streams, and the bedrock coverage (soil, sediments) is 0.5 to $1 \mathrm{~m}$ thick. The presence of a continuous soil cover is important for maintaining a regular supply of vadose water to the cave. The infiltration is local due to the sub-horizontal orientation of bedrock foliation (subparallel to the passage) and fissures (sub-vertical), and all observations indicate that vadose water originates directly from meteoric water. Dripwater in the FM gallery is accordingly found to originate from a catchment area directly above the passage with a radius of less than $100 \mathrm{~m}$ (Skoglund, unpublished). The bedrock overlying the FM gallery is about $30 \mathrm{~m}$ (Fig. 1c), whereas it is about $20 \mathrm{~m}$ thick above the Blokkhuset passage (B, Fig. 1b, c).

Temperature, drip rates, and relative humidity were monitored from July through September 1998 and April through September 1999 (Hansen, 2001). The temperature in FM was $+3.22 \pm 0.10^{\circ} \mathrm{C}$ and the soil temperature above the cave was $+2.77 \pm 0.07^{\circ} \mathrm{C}$. A weak reduction during the winter months and weak increase during the summer season indicate that the FM gallery (Fig. 1b) is situated too close to the entrance to be characterised by "constant" deep cave conditions (Hansen, 2001). Drip rates for two positions in FM were $1.49 \pm 0.20 \mathrm{ml} / 24 \mathrm{~h}$ and $1.21 \pm 0.76 \mathrm{ml} / 24 \mathrm{~h}$, and relative humidity was about $85 \%$. No response in drip rate variability was observed during the monitoring (07-09/1998 and 0509/1999) despite fluctuations in meteoric precipitation, suggesting that a certain reservoir capacity is associated with the infiltration and percolation system. Hansen (2001) concluded that both temperature, drip rates, and relative humidity from Okshola/FM were stable during the observation periods, echoing findings from the deeper Søylegrotta further south (Einevoll and Lauritzen, 1994). Drip water $(n=50)$ was collected for a longer period (07/1998-06/2000) and gave an average $\delta^{18} \mathrm{O}$ of the drip water $\left(\delta^{18} \mathrm{O}_{\mathrm{w}}\right)$ of $-10.56 \pm 0.26 \%$ o VSMOW, leading Hansen (2001) to suggest it represented mixing of precipitation from all seasons. This implies that the system has a certain storage capacity and that the reservoir time is "long", in agreement with the drip rate information.

\subsection{The speleothems}

The FM3 stalagmite (Fig. 1f) was retrieved from its growth position in the FM gallery in June 1997, and was most likely still active when collected. The vertical growth axis is $144 \mathrm{~mm}$, the basal diameter c. $80 \mathrm{~mm}$, and the apex diameter c. $30 \mathrm{~mm}$. The stalagmite grew on a sand bed and showed no root (calcreted drip-pit) extending into the sediment, so the intact base was collected. It is composed of white, columnar calcite and has a pristine appearance. Continuous, elongated crystals can be traced through alternating opaque and translucent zones (Fig. 1f) along the growth direction, however, the basal $\sim 6 \mathrm{~mm}$ differs from this and displays calcite crystals of non-uniform orientation. Visible detritus is present along a few of the sharply descending growth layers but not in the horizontal apex zone. No visual evidence of corrosion or depositional hiatuses is observed.

The Oks82 (820913-2) stalagmite (Fig. 1g) was inactive when collected from its growth position between blocks on a slope in the B gallery in 1982. This passage is situated between the main entrance and the FM gallery (Fig. 1b). The stalagmite is $74 \mathrm{~mm}$ from base to top, and has a broad basal diameter of c. $120 \mathrm{~mm}$. In cross-section the stalagmite reveals that the apex zone has a uniform diameter (c. $50 \mathrm{~mm}$ ) from base to top, and that a lateral displacement of the growth axis occurred about $35 \mathrm{~mm}$ above the base. The Oks 82 stalagmite is composed of massive calcite of a multi-coloured, banded appearance (Fig. 1g). The high variability in colour and band orientation suggests highly shifting environmental conditions and/or dripwater composition. Its basal part is rich in fine to coarse detritus/minerogenic particles cemented by calcite.

Several thin-walled soda straw stalactites from the FM gallery (Fig. 1b) were collected in 1997. They were commonly about $20 \mathrm{~cm}$ long and $0.5-1 \mathrm{~cm}$ in diameter. Because the majority of the stalactites in this gallery appeared to be of a uniform length it was assumed that this represented the post-glacial accumulation.

Albeit being a shallow cave, with percolation pathways developed in foliated marble and mica schist implying short storage time, neither of the stalagmites were found to contain regular luminescent lamination that could be used for investigating the presence and style of annual calcite accretion. Both visible and luminescent lamination in Oks82 appears discontinuous (flowstone-like character), whereas the luminescence intensity in FM3 is too diffuse/weak for analysis, agreeing with low organic content suggested by the pristine appearance.

\section{Methods}

The FM3 and Oks82 stalagmites were cut into four slabs each parallel to their growth axes. From both stalagmites, one centre slab was dedicated for TIMS U-Th dating, whereas the 

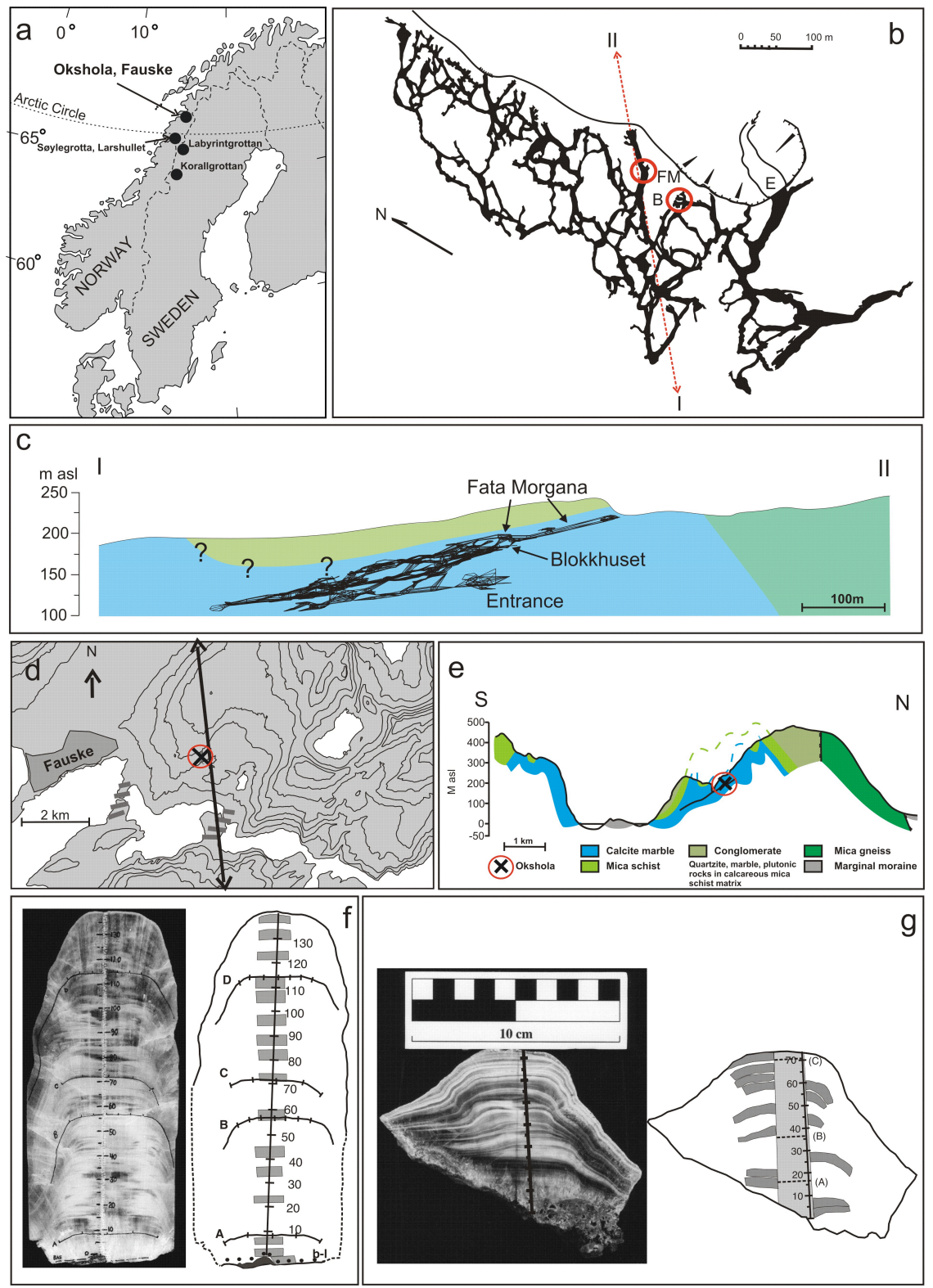

Fig. 1. (a) Map of Scandinavia indicating the location of Fauske, and of the caves mentioned in this study. The stalagmites presented here are FM3 and Oks82 from Okshola (Fauske, northern Norway). Data from Søylegrotta (SG93, SG92-4, SG95), Larshullet (L03), Korallgrottan (K1, K11) and Lab yrintgrottan (L4) are used for comparison and discussion (see text and Fig. 5 for references). (b) Map of the NW section of Okshola, with growth locations of FM3 (FM = Fata Morgana) and Oks82 (B = Blokkhuset) marked in relation to the entrance (E). The vertical profile along the broken line from I to II is shown in Fig. 1c. (c) Vertical profile from I to II (along line in Fig. 1b) showing the bedrockcontrolled, sub-horizontal orientation of the Okshola cave. The Fata Morgana gallery is situated slightly higher than the Blokkhuset passage; both are positioned below a local height but with Blokkhuset closer to the surface, the escarpment and the entrance. (d) Topographic map of the Fauske-Finneid area. N-S line indicates the approximate position of the vertical profile shown in Fig. 1e, and the location of Okshola is marked with $\mathrm{x}$. Two marginal moraines ridges (marked with grey, parallel lines), are correlated to the Misvær-Finneid Event and radiocarbon dated to $9550 \pm 200{ }^{14} \mathrm{C}$ years BP and $9300 \pm 200{ }^{14} \mathrm{C}$ years BP (Andersen, 1975; Andersen et al., 1981). (e) Vertical profile showing the large-scale topography and bedrock geology of a N-S section (Fig. 1f) of the valley with the Okshola cave situated in the northern valley side. Note the position of the youngest marginal moraine in the valley. (f) Photo and sketch of FM3. The vertical growth axis starts at -4 mm at the base of the stalagmite and ends at $140 \mathrm{~mm}$ at its top, grey boxes indicate positions of TIMS U-Th dated samples, labels b-1 and A-D denotes growth horizons tested for isotopic equilibrium. (g) Photo and sketch of Oks82. The vertical growth axis starts at $0 \mathrm{~mm}$ at the base of the stalagmite and ends at $74 \mathrm{~mm}$ at its top. The light grey zone along the growth axis indicates the slab used for stable isotope measurements, whereas dark grey zones represent samples for TIMS U-Th dating. (A-C) denotes growth horizons tested for isotopic equilibrium. 
mirroring centre slab was dedicated for stable isotope analysis. This ensures that both U-Th and stable isotope analyses refer to identical axes.

Subsamples were cut from the stalagmite slabs using a dental drill with a diamond-coated disc. Following the description of Lauritzen and Lundberg (1999), preparation for U-Th analysis included a two-step heating $\left(500,900^{\circ} \mathrm{C}\right)$, dissolution in $7 \mathrm{~N} \mathrm{HNO}_{3}$, and gentle heating for $5 \mathrm{~h}$ to equilibrate after addition of a triple $\left({ }^{233} \mathrm{U}-{ }^{236} \mathrm{U}-{ }^{229} \mathrm{Th}\right)$ carrier. Chemical separation and purification of $U$ and Th included scavenging with $\mathrm{Fe}$-precipitation, two sets of anion-exchange columns and final drydown with $\mathrm{H}_{3} \mathrm{PO}_{4}$. U and Th fractions were loaded on single filaments with silica gel and graphite, respectively. Isotopic determinations were acquired on a ThermoFinnigan MAT 262 mass spectrometer using the SEM in peak-jumping mode (e.g. Lauritzen and Lundberg, 1999; Goldstein and Stirling, 2003) at the Department of Earth Science, University of Bergen. Mass calibration was performed routinely when switching from lighter elements to $\mathrm{U}$ and the in-house standard (B-018, Eemian flowstone) was analysed prior to runs of unknown samples. All U-Th ages are reported with $2 \sigma$ uncertainties and as years before AD 2000.

Powder (80-95 $\mu \mathrm{g}$ ) for stable isotope analysis was collected at $0.5 \mathrm{~mm}$ intervals along the vertical growth axis using a $0.5 \mathrm{~mm}$ diameter diamond-tipped dental drill. Powder was also collected along growth horizons for isotopic equilibrium tests ("Hendy tests"). The analyses were done at the GSM Laboratory, University of Bergen, using a Finnigan MAT 251 mass spectrometer and an automatic on-line carbonate preparation device ("Kiel device"). Standard carbonate samples have analytical $1 \sigma$ uncertainty of $\pm 0.06 \%$ o and $\pm 0.07 \%$ for $\delta^{13} \mathrm{C}$ and $\delta^{18} \mathrm{O}$, respectively. Results are reported as \%o VPDB, using the NIST (NBS) 19 standard as reference.

From the FM3 stalagmite, sixteen subsamples of $3-5 \mathrm{~mm}$ vertical thickness (grey zones, Fig. 1f), weighing 1.3-2.9g were analysed by the TIMS U-Th technique. Subsamples for stable isotope analysis were taken at $0.5 \mathrm{~mm}$ intervals along the vertical growth axis, and at $5-10 \mathrm{~mm}$ intervals along five individual growth horizons (A-D, and base-level, Fig. 1f). A minimum of five subsamples were analysed from each horizon and the length of the sampled horizons are $30-40 \mathrm{~mm}$. From the Oks82 stalagmite, fourteen subsamples of 3-4 mm vertical thickness (grey zones, Fig. 1g), weighing 0.7-3.4 g, were analysed by the TIMS U-Th technique. Subsamples for stable isotope analysis were taken at $0.5 \mathrm{~mm}$ intervals along the vertical growth axis, and at $1-2 \mathrm{~mm}$ intervals along three individual growth horizons (A-C, Fig. 1g). A minimum of four subsamples were analysed and the length of the sampled horizons are 4 to $8 \mathrm{~mm}$. In addition, five subsamples of 1.2-3.1 g were taken from three different soda straw stalactites and analysed by the TIMS U-Th technique. Depending on the thickness of the walls of the straw, and how massive the calcite was, $1-6 \mathrm{~cm}$ of stalactite was used for dating.

\section{Results}

\subsection{TIMS U-Th analyses}

The analytical results from the TIMS U-Th analyses of stalagmites and stalactites are presented in Table 1. All the UTh isotope ratios are activity ratios, and all errors are $2 \sigma$. Both uncorrected and corrected ages are reported as years before $\mathrm{AD} 2000$. The $\mathrm{U}$ concentration, $\left[{ }^{238} \mathrm{U}\right]$, varies between 0.29 to $0.83 \mu \mathrm{g} \mathrm{g}^{-1}$ for FM3, 0.37 to $1.41 \mu \mathrm{g} \mathrm{g}^{-1}$ for Oks82, and 0.53 to $0.76 \mu \mathrm{g} \mathrm{g}^{-1}$ for the stalactites. The Th concentration, $\left[{ }^{232} \mathrm{Th}\right]$, ranges between 0.04 to $0.78 \mu \mathrm{g} \mathrm{g}^{-1}$ for FM3, 0.38 to $3.50 \mu \mathrm{g} \mathrm{g}^{-1}$ for Oks82, and 0.28 to $1.39 \mu \mathrm{g} \mathrm{g}^{-1}$ for the stalactites. The Oks82 stalagmite has overall lower ${ }^{234} \mathrm{U}^{238} \mathrm{U}$ activity ratios, $\left({ }^{234} \mathrm{U} /{ }^{238} \mathrm{U}\right)_{A}$, than the FM3 stalagmite (Table 1). In addition, the $\left({ }^{234} \mathrm{U} /{ }^{238} \mathrm{U}\right)_{A}$ values of FM3 show a general decrease from base to top, whereas the $\left({ }^{234} \mathrm{U} /{ }^{238} \mathrm{U}\right)_{A}$ of $\mathrm{Oks} 82$ show higher variation and increase from base to top. The two stalagmites appear to have been formed from drip water of different geochemical signatures, suggesting distinct differences in percolation pathway characteristics. Decreasing $\left({ }^{234} \mathrm{U} /{ }^{238} \mathrm{U}\right)_{A}$ towards the top is explained by a gradual leaching of $U$ from the overburden and host rock, indicative of a relatively stable percolation system. Increasing $\left({ }^{234} \mathrm{U} /{ }^{238} \mathrm{U}\right)_{A}$ suggests recurring alterations along the percolation pathway, exemplified by the lateral displacement in the apex zone of Oks82 at about $35 \mathrm{~mm}$ above basis where both $\left[{ }^{238} \mathrm{U}\right]$ and $\left[{ }^{232} \mathrm{Th}\right]$ are overall higher below than above. The stalactite samples have $\left[{ }^{238} \mathrm{U}\right]$ similar to the FM3 stalagmite or higher (Table 1), quite high $\left[{ }^{232} \mathrm{Th}\right]$, and $\left({ }^{234} \mathrm{U} /{ }^{238} \mathrm{U}\right)_{\mathrm{A}}$ resembling the uppermost FM3 values (last 4000 years), adding support to FM3 being representative for the FM gallery and deposited under stable conditions.

\subsection{Age models}

The majority of the U-Th analyses in this study show activity ratios of ${ }^{230} \mathrm{Th} /{ }^{232} \mathrm{Th},\left({ }^{230} \mathrm{Th} /{ }^{232} \mathrm{Th}\right)_{\mathrm{A}}$, below $100(\mathrm{Ta}-$ ble 1). The accuracy of age calculations is sensitive to the presence of non-authigenic ${ }^{230} \mathrm{Th}$, which must hence be detected and corrected for. The impact of correction of nonauthigenic ${ }^{230} \mathrm{Th}$ depends on the concentrations of $\mathrm{U}$ and $\mathrm{Th}$, the analytical precision, and age. In general, the impact is very large on young samples $(<5 \mathrm{ka})$ and minor for older samples ( $>10 \mathrm{ka})$. Initial ${ }^{230} \mathrm{Th} / 232 \mathrm{Th}$ activity ratios, i.e. $\left({ }^{230} \mathrm{Th} /{ }^{232} \mathrm{Th}\right)_{\mathrm{A} 0}$, most likely varies during formation of a stalagmite (e.g. Hellstrom, 2006; Linge et al., 2009), hence adopting a single correction factor might not correct, only shift, the offset from true calcite formation age. Moreover, the threshold for correction for non-authigenic ${ }^{230} \mathrm{Th}$ depends on the analytical precision. The higher the precision the higher $\left({ }^{230} \mathrm{Th} /{ }^{232} \mathrm{Th}\right)_{\mathrm{A}}$ must be in order for uncorrected and corrected ages to be statistically indistinguishable: for the $2 \sigma$ age range $( \pm>0.5 \%)$ not to overlap between uncorrected and corrected values the activity ratio has to be $>130$, 
Table 1. TIMS U-Th results from the FM3 and Oks82 stalagmites and the FM stalactites. Ages are in years before AD 2000, and errors are $2 \sigma$. Bold laboratory numbers refer to analyses used in age models, numbers in italics signify analyses not included in the age models.

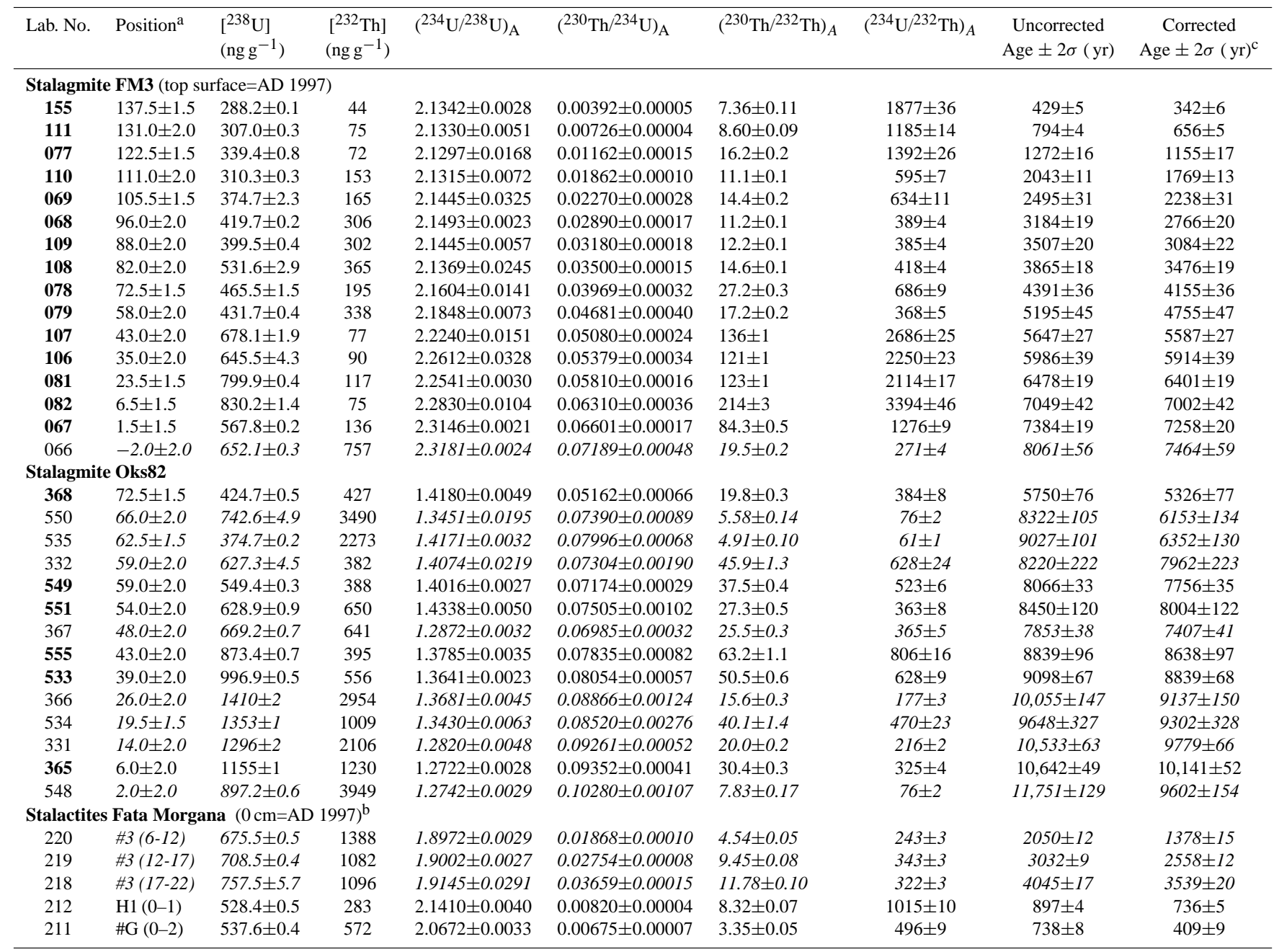

${ }^{\text {a }}$ Centre position of TIMS subsample along growth axis.

${ }^{\mathrm{b}}$ For stalactites, numbers in brackets refer to $\mathrm{cm}$ interval from the active tip.

${ }^{\mathrm{c}}$ Growth rates in $\mu \mathrm{m} / \mathrm{yr}$ between accepted subsamples (Lab. No): For FM3: 7.37 (surface-155), 20.70 (155-111), 17.03 (111-077), 18.7 (077-110), 11.70 (110-069), 17.99 (069-068), 25.16 (068-109), 15.31 (109-108), 13.99 (108-078), 24.16 (078-079), 18.03 (079-107), 24.46 (107-106), 23.61 (106-081), 28.29 (081-082), 19.53 (081-067). For Oks82: 5.56 (368-549), 20.16 (549-551), 17.35 (551-555), 19.90 (555533), $25.30(533-365)$.

whereas a $2 \sigma$-age precision better than $0.3 \%$ requires an activity ratio of about 200 (cf. Richards and Dorale, 2003).

Our approach, when constructing age models based on the data in Table 1, has been to minimize the impact of correction by only accepting analyses that have $\left[{ }^{238} \mathrm{U}\right] /\left[{ }^{232} \mathrm{Th}\right] \geq 0.9$, a $2 \sigma$-age uncertainties $\leq 1.4 \%$, and stratigraphic consistency. Hence, from the FM3 stalagmite we have accepted 15 analyses, i.e. all except the basal one (\#066 Table 1). Subsamples from Oks82 generally have high [ $\left.{ }^{232} \mathrm{Th}\right]$, causing either unstable or low-intensity U signals, and hence variable precision. Based on the stated data selection criteria, we have accepted six out of 14 analyses (Table 1, \#368, 549, 551, 555, 533, and 365). In addition, analysis \#367 is omitted because of its strong deviation from stratigraphic order as observed in the calculated age and $\left({ }^{234} \mathrm{U} /{ }^{238} \mathrm{U}\right)_{\mathrm{A}}$. Because of the overall low $\left({ }^{230} \mathrm{Th} /{ }^{232} \mathrm{Th}\right)_{\mathrm{A}}$ for the accepted analyses, we chose to use the corrected ages assuming an $\left({ }^{230} \mathrm{Th} /{ }^{232} \mathrm{Th}\right)_{\mathrm{A} 0}$ of 1.5 rather than using the uncorrected ages. Although this value may not be accurate for the cave or uniform during the formation of the stalagmite, it is in agreement with an average $\left({ }^{230} \mathrm{Th} /{ }^{232} \mathrm{Th}\right)_{\mathrm{A} 0}$ of $1.47 \pm 0.66$ found by Linge et al. (2009) when comparing annual and U-Th age models 


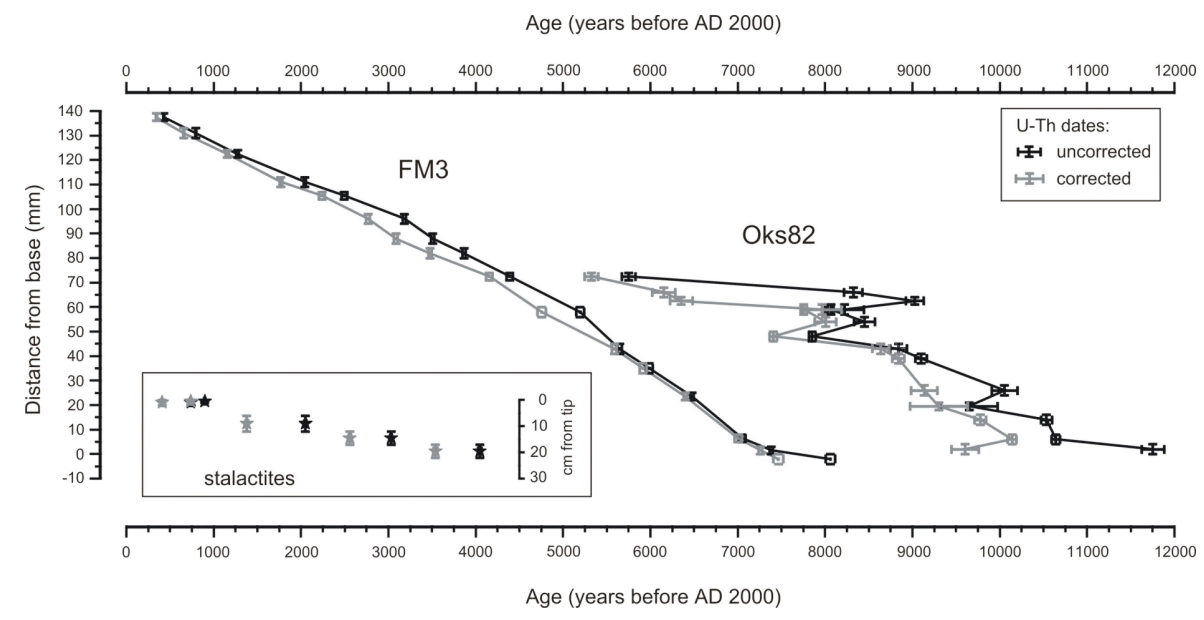

Fig. 2. TIMS U-Th ages, uncorrected (black) and corrected (grey), for the stalagmites FM3 and Oks82, as well as from three soda straw stalactites from Okshola (Table 1). FM3 shows minor correction for its older and younger parts, whereas the middle part has significant corrections. TIMS U-Th analyses from Oks82 and the stalactites reveal high concentrations of ${ }^{232} \mathrm{Th}$ and thus significantly younger ages when corrected for initial ${ }^{230} \mathrm{Th}$ (Table 1).

from a laminated stalagmite. Figure 2 shows the uncorrected and corrected ages from the two stalagmites and the three stalactites. The corrected ages of accepted analyses provide the chronological framework for the growth rate and stable isotope records used in this study.

Based on the six accepted analyses from the Oks82 stalagmite, the U-Th ages reveal that deposition started before $10100 \mathrm{yr}$ and terminated after $5300 \mathrm{yr}$ (Table 1, Fig. 2). The average growth rate of the Oks82 stalagmite is close to $15 \mu \mathrm{m} / \mathrm{yr}$. A maximum rate of $\sim 25 \mu \mathrm{m} / \mathrm{yr}$ is found around $9500 \mathrm{yr}$. A period of reduced growth rate is centred around $8300 \mathrm{yr}$, a brief interval of higher than average growth rate is centred at $7875 \mathrm{yr}$, and the final drop in growth rate occurs after $7750 \mathrm{yr}$ and coincides with the displacement of the apex zone.

The formation of the FM3 stalagmite commenced before $7200 \mathrm{yr}$ and continued until when collected in June AD1997 (Table 1, Fig. 2). The growth rate dataset for FM3 provides more details than for Oks 82 because it is based on $15 \mathrm{U}$ Th ages. The average growth rate is close to $19 \mu \mathrm{m} / \mathrm{yr}$. The growth rate for the last 1000 years changes from $17 \mu \mathrm{m} / \mathrm{yr}$ (1155-656 yr), to $21 \mu \mathrm{m} / \mathrm{yr}$ (656-342 yr), and then falls to $\sim 7 \mu \mathrm{m} / \mathrm{yr}$ (last 340 years). Periods of relatively slow growth are centred around $5200 \mathrm{yr}, 3800 \mathrm{yr}$, and $2000 \mathrm{yr}$. Higher than average growth rate occurred between c. 7000 and $5600 \mathrm{yr}$, and later during two briefer periods centred around $4450 \mathrm{yr}$, and $500 \mathrm{yr}$.

The stalactites appeared to be younger than anticipated, with the longest soda straw being younger than $5000 \mathrm{yr}$ (Table 1, Fig. 2). The three stalactites show variable extension rates. Stalactite \#3 suggests a uniform or increase in rate towards the present from $51 \mu \mathrm{m} / \mathrm{yr}(3540-2560 \mathrm{yr}), 47 \mu \mathrm{m} / \mathrm{yr}$ (2560-1380 yr), to $65 \mu \mathrm{m} / \mathrm{yr}$ (1380-3 yr). Extrapolation of the oldest extension rate to the roof yields an initiation of the soda straw formation around $4800 \mathrm{yr}$. The tip of stalactite $\mathrm{H}$, however, shows a low rate of $7 \mu \mathrm{m} / \mathrm{yr}$ for the past $740 \mathrm{yr}$, whereas stalactite $\mathrm{G}$ yields an extension rate of $24 \mu \mathrm{m} / \mathrm{yr}$ for the past $410 \mathrm{yr}$.

\subsection{Stable isotopes - isotopic equilibrium testing and stratigraphy}

Calcite must be precipitated in isotopic equilibrium with its dripwater in order to provide records of absolute temperature (e.g. Fantidis and Ehhalt, 1970; Hendy, 1971; Gascoyne, 1992; Mickler et al., 2006; Lachniet, 2009). This is commonly tested for by performing the "Hendy test", which investigates the behaviour and covariation of $\delta^{18} \mathrm{O}_{\mathrm{c}}$ and $\delta^{13} \mathrm{C}_{\mathrm{c}}$ along growth horizons, and where a strong covariation is taken as indicative of kinetic fractionation.

Growth horizons from both FM3 and Oks82 typically show less negative values of $\delta^{18} \mathrm{O}_{\mathrm{c}}$ and $\delta^{13} \mathrm{C}_{\mathrm{c}}$ with distance from apex (Fig. 3a). Such behaviour implies that kinetic fractionation has affected the isotopic composition of both stalagmites, and that the stratigraphic records cannot be considered as straightforward temperature-dependent proxy archives. The location the growth horizons tested for isotopic equilibrium conditions are shown in Fig. 3b (Oks82 upper panel, FM3 lower panel), and according to the $r^{2}$-values the degree of kinetic fractionation increase from base to top in both stalagmites.

The stable isotope stratigraphy is shown in Fig. 3b (Oks82 upper panel, FM3 lower panel), together with the positions of the U-Th dates used in the age models (black symbols). As common for Norwegian stalagmites (e.g. Lauritzen, 1995; Linge et al., 2001a, b, 2009), the stable isotope records from FM3 and Oks82 display a strong covariation. 


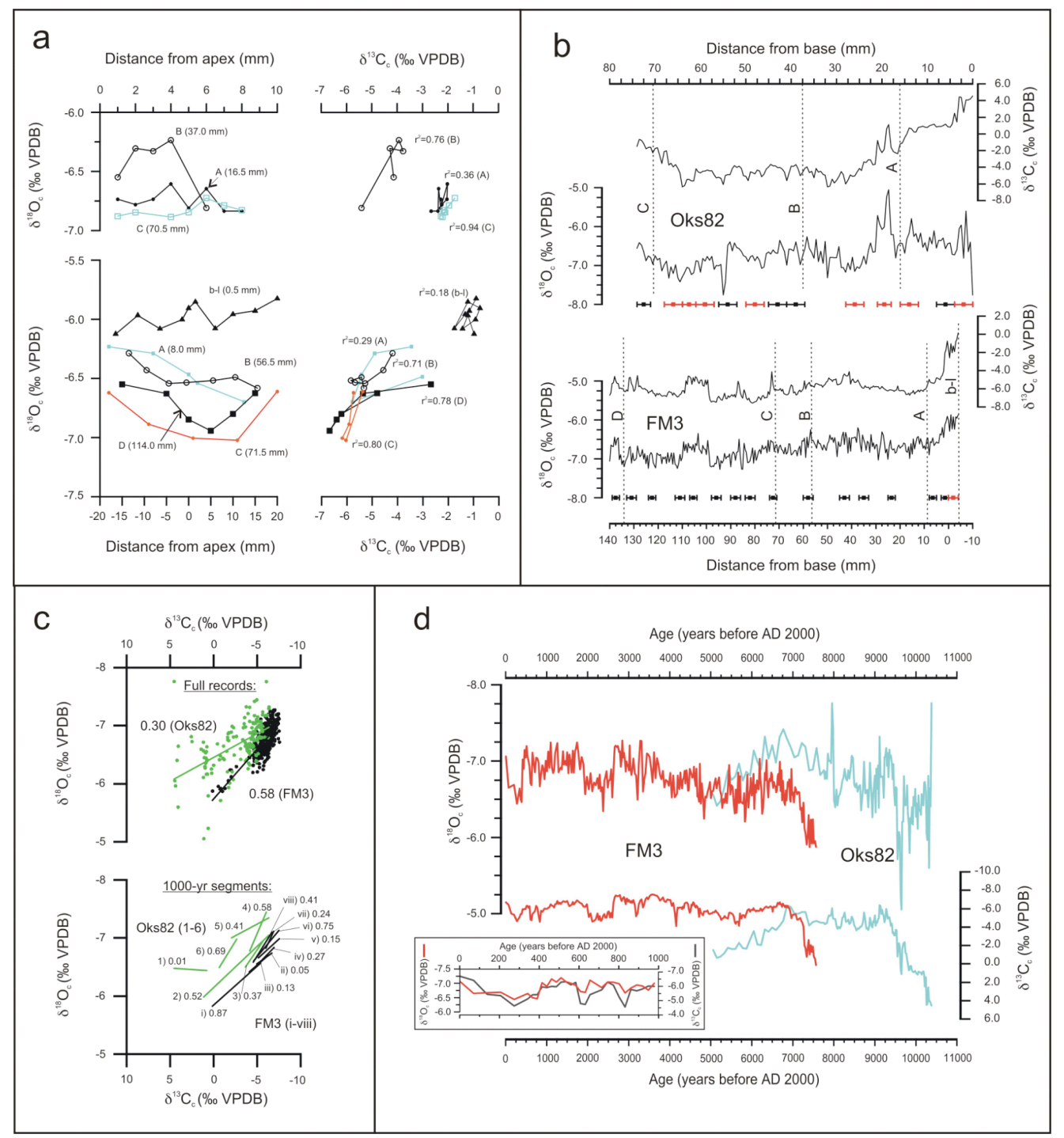

Fig. 3. (a) Isotopic equilibrium tests for growth horizons from Oks82 (upper y-axis) and FM3 (lower y-axis). Plots of $\delta^{18} \mathrm{O}_{\mathrm{c}}$ versus distance from the vertical growth axis (left $\mathrm{x}$-axis) show how $\delta^{18} \mathrm{O}_{\mathrm{c}}$ varies with distance from apex (apex position=1 for Oks82, and =0 for FM3). Kinetic enrichment is indicated by the pattern along several of the individual growth horizons. Plots of $\delta^{18} \mathrm{O}_{\mathrm{c}}$ versus $\delta^{13} \mathrm{C}_{\mathrm{c}}$ (right $\mathrm{x}$-axis) show the degree of covariation between the two isotopes, some indicative of kinetic fractionation (high $r^{2}$-values). For Oks 82 , the variability from base to top is $0.23(\mathrm{~A}), 0.57(\mathrm{~B})$ and $0.16 \%$ (C) for $\delta^{18} \mathrm{O}_{\mathrm{c}}$ and $0.64(\mathrm{~A}), 1.63(\mathrm{~B})$ and $0.55 \%$ (C) for $\delta^{13} \mathrm{C}_{\mathrm{c}}$ (Fig. $3 \mathrm{a}$, upper panels). The corresponding covariation of $\delta^{18} \mathrm{O}_{\mathrm{c}}$ and $\delta^{13} \mathrm{C}_{\mathrm{c}}\left(r^{2}\right.$-values) is $0.36(\mathrm{~A}), 0.76(\mathrm{~B})$ and $0.94(\mathrm{C})$. For FM3, the variability from base to top is $0.30(\mathrm{~b}-1), 0.46(\mathrm{~A}), 0.30(\mathrm{~B}), 0.41(\mathrm{C})$ and $0.39 \%$ (D) for $\delta^{18} \mathrm{O}_{\mathrm{c}}$, and $1.01(\mathrm{~b}-1), 2.76(\mathrm{~A}), 1.64(\mathrm{~B}), 0.81$ (C) and 4.00 (D) for $\delta^{13} \mathrm{C}_{\mathrm{c}}$ (Fig. 3a, lower panels). The corresponding covariation of $\delta^{18} \mathrm{O}_{\mathrm{c}}$ and $\delta^{13} \mathrm{C}_{\mathrm{c}}\left(r^{2}\right.$-values) is $0.18(\mathrm{~b}-1), 0.29$ (A), 0.71 (B), $0.80(\mathrm{C})$, and 0.78 (D). (b) The stable isotope stratigraphy from Oks82 (upper X-axis) and FM3 (lower X-axis). The positions of the U-Th dates are marked blow each set of curves, where red symbols indicate dates not used in the final age models. Broken, vertical lines indicate the positions of the isotopic equilibrium tests (Fig. 3a). (c) Covariation of $\delta^{18} \mathrm{O}_{\mathrm{c}}$ and $\delta^{13} \mathrm{C}_{\mathrm{c}}$ along the growth axes. The upper panel shows $r^{2}$-values for the covariation for the full isotope stratigraphy of Oks82 (green) and FM3 (black). The lower panel shows $r^{2}$-values for the covariation along $\sim 1000 \mathrm{yr}$ segments from Oks82 (green) and FM3 (black). The segments from Oks82 are: 1) 10.3-10 ka, 0-9.5 mm; 2) 9.9-9.0 ka, 10-34.5 mm, location of Hendy test A; 3) 8.9-8.0 ka, 35-54 mm, location of Hendy test B; 4) 7.9-7.0 ka, 54.5-63 mm; 5) 6.0-6.0 ka, 63.5$68.5 \mathrm{~mm}$; 6) $5.9-5.0 \mathrm{ka}, 69-74 \mathrm{~mm}$, location of Hendy test C. The segments from FM3 are: i) 7.5-7.0 ka, $-4-6 \mathrm{~mm}$, location of Hendy test b-1; ii) $6.9-6.0 \mathrm{ka}, 7-32.5 \mathrm{~mm}$, location of Hendy test A; iii) $5.9-5.0 \mathrm{ka}, 33-53.5 \mathrm{~mm}$; iv) $4.9-4.0 \mathrm{ka}$, 54-74.5 mm, location of Hendy tests B and C; v) 3.9-3.0 ka, 75-90 mm; vi) $2.9-2.0 \mathrm{ka}, 90.5-108 \mathrm{~mm}$; vii) $1.9-1.0 \mathrm{ka}, 108.5-125 \mathrm{~mm}$, location of Hendy test D; viii) $0.9-0 \mathrm{ka}$, $125.5-140 \mathrm{~mm}$. (d) The stable isotope time-series covering the last $\sim 10000$ years from Okshola composed by Oks82 (blue) and FM3 (red). The upper curves show the $\delta^{18} \mathrm{O}_{\mathrm{c}}$ data, whereas the lower curves show the $\delta^{13} \mathrm{C}_{\mathrm{c}}$ data. Inset shows the $\delta^{18} \mathrm{O}_{\mathrm{c}}(\mathrm{red})$ and $\delta^{13} \mathrm{C}_{\mathrm{c}}(\mathrm{black})$ variation from FM3 for the last 1000years. 
Figure $3 \mathrm{c}$ (upper panel) show that the covariation of $\delta^{18} \mathrm{O}_{\mathrm{c}}$ and $\delta^{13} \mathrm{C}_{\mathrm{c}}$ along the growth axis, expressed as $r^{2}$, is 0.58 for FM3 and $0.30 \mathrm{Oks} 82$. When plotted for $\sim 1000$-year segments (see lower panel in Fig. 3c and figure caption for details), the degree of covariation is found to vary with time/distance from base. The cause of this apparent kinetic fractionation effect is not obvious because i) evaporation of water seems unlikely within a blind cave passage with low cave temperature and relatively high humidity, and ii) the short vegetation growth season and annual average low soil$\mathrm{CO}_{2}$ production suggest low $\mathrm{P}_{\mathrm{CO}_{2}}$ in the dripwater and rule out rapid degassing of $\mathrm{CO}_{2}$. Using the degree of covariation of $\delta^{18} \mathrm{O}_{\mathrm{c}}$ and $\delta^{13} \mathrm{C}_{\mathrm{c}}$ in order to determine whether $\delta^{18} \mathrm{O}_{\mathrm{c}}$ was in equilibrium with the oxygen isotope composition with the dripwater seems misleading under such conditions, and we thus chose to treat the stalagmites as deposited in quasiisotopic equilibrium. Attempting a clear one-to-one conversion of the stable oxygen isotopes with temperature is futile here because the cave is not characterised by true "deep cave" conditions. We have restricted our interpretation to be based on relative changes and focussed on whether it is feasible to attribute these to either changes in $\mathrm{T}$ or in precipitation (amount and composition).

\subsection{Stable isotope time-series}

The stable isotope time-series are presented on age models based on corrected U-Th ages (Fig. 3d). Oks82 shows rapid, high amplitude shifts in the $\delta^{18} \mathrm{O}_{\mathrm{c}}$ record from c. $10380 \mathrm{yr}$ to about $7750 \mathrm{yr}$ (Fig. 3d, upper panel) when the growth rate drops. The basal data point (c. $10380 \mathrm{yr}$ ) in the nonsmoothed Oks82 $\delta^{18} \mathrm{O}_{\mathrm{c}}$ curve is very depleted $(-7.75 \%$ ). This is succeeded by a step-wise enrichment (max at c. 10300 and $9900 \mathrm{yr}$ ), culminating in a distinct enriched interval at c. 9650-9550 yr. A nearly $200 \mathrm{yr}$ long enriched period $(8175-8000 \mathrm{yr})$ is followed by a prominent depletion at c. $7950 \mathrm{yr}$. A gradual enrichment trend accompanies the reduction in growth rate towards the termination around 5000 yr. The $\delta^{13} \mathrm{C}_{\mathrm{c}}$ record (Fig. 3d, lower panel) is highly enriched $(>-3 \%$ ) near the base, decreases to more "typical" values $(<-3 \%$ ) between 9500 and $6300 \mathrm{yr}$ ago, and then returns to enriched values $(>-3 \%$ ) as the growth rate decreases.

FM3 display a $\sim 1 \%$ o change from base to top in the $\delta^{18} \mathrm{O}_{\mathrm{c}}$ record (Fig. 3d, upper panel), where the older half of the $\delta^{18} \mathrm{O}_{\mathrm{c}}$ record (c. 7550 to $4000 \mathrm{yr}$ ) displays overall more enriched values than the younger half. Enriched $\delta^{18} \mathrm{O}_{\mathrm{c}}$ episodes $(>-6.55 \%$ o ) occur around 7550-7100 yr, $7000 \mathrm{yr}, 6700 \mathrm{yr}$, $6600 \mathrm{yr}, 6400 \mathrm{yr}, 6275 \mathrm{yr}, 5900 \mathrm{yr}, 5600 \mathrm{yr}, 5300 \mathrm{yr}, 5000 \mathrm{yr}$, $4800 \mathrm{yr}, 4100 \mathrm{yr}, 3200 \mathrm{yr}, 2600 \mathrm{yr}, 2500 \mathrm{yr}, 2375 \mathrm{yr}, 1950 \mathrm{yr}$, $370 \mathrm{yr}$ and $275 \mathrm{yr}$. The $\delta^{13} \mathrm{C}_{\mathrm{c}}$ record (Fig. 3d, lower panel) resembles that of $\delta^{18} \mathrm{O}_{\mathrm{c}}$ except for the long-term trend; it shows most depleted values in the middle part (3500-2600 yr) with overall enriched values before and after. The elevated $\delta^{13} \mathrm{C}_{\mathrm{c}}$ values $(>-3 \%$ ) of the basal part of the record coincide with the zone of non-uniform crystal orientation (lower $<6 \mathrm{~mm}$ ). A basal enrichment is seen for both isotopes, coinciding with the zone of non-uniform crystal orientation (lower $6 \mathrm{~mm}$ ) where, according to the "Hendy test", the stable isotope values are not affected by kinetic fractionation.

Although both the Oks82 and FM3 stalagmites were active and show similar stable isotope trends between c. 7550 and $5050 \mathrm{yr}$ (Fig. 3d), their absolute isotope values and growth rates differ during this time. The two $\delta^{18} \mathrm{O}_{\mathrm{c}}$ records show an offset of about $0.4 \%$, but corresponding large-scale enrichment trends between $\sim 6750$ and $5000 \mathrm{yr}$, and the enriched episodes noted above for FM3 are also found in the Oks82 record between c. 7300 and 5300 yr. Despite the $\delta^{18} \mathrm{O}_{\mathrm{c}}$ data from Oks82 being significantly depleted compared to the basal FM3 data, they are of similar absolute values as the younger part of the $\delta^{18} \mathrm{O}_{\mathrm{c}} \mathrm{FM} 3$ record. Because of this offset, no correction has been undertaken for marine changes in Standard Mean Ocean Water (SMOW) through the Holocene. A similar situation, covariance and an offset of about $0.3 \%$ o has also been reported for "deep" stalagmites from Søylegrotta (Linge et al., 2001).

\section{Discussion}

\subsection{Stable carbon isotope patterns for the last 1000 years}

The last 1000 years are represented by the upper $14.5 \mathrm{~mm}$ (i.e. 30 data points) of the FM3 stable isotope record. The $\delta^{13} \mathrm{C}_{\mathrm{c}}$ record (inset, Fig. $3 \mathrm{~d}$ ) shows a pattern of fluctuating values (1000-600 yr), depleted values (600-400 yr), enriched values (400-100 yr), and with depleted values again towards the present-day.

$\delta^{13} \mathrm{C}$ values of cave calcite $\left(\delta^{13} \mathrm{C}_{\mathrm{c}}\right)$ rely upon the composition of the dripwater and the rate of degassing, which again is controlled by the quantity of air in the cave, its $\mathrm{CO}_{2}$ content and the cave ventilation. The $\mathrm{P}_{\mathrm{CO}_{2}}$ of the cave air is controlled by the vegetation at the surface and the degree of air ventilation in the cave (e.g. Baldini et al., 2006, 2008), and as $\mathrm{CO}_{2}$ is expelled to accommodate the difference in $\mathrm{P}_{\mathrm{CO}_{2}}$ of soil waters and the cave air the calcite saturation of dripwaters increases, and calcite can be precipitated. Both equilibrium-degassing and kinetically-enhanced degassing can lead to $\delta^{13} \mathrm{C}$ enrichment of the dripwater (Usdowski and Hoefs, 1990). An inverse relationship exists between soil- $\delta^{13} \mathrm{C}$ and soil- $\mathrm{P}_{\mathrm{CO}_{2}}$ (Rightmire, 1978; Hesterberg and Siegenthaler, 1991), implying that under high- $\mathrm{P}_{\mathrm{CO}_{2}}$ conditions the $\delta^{13} \mathrm{C}$ of soil- $\mathrm{CO}_{2}$ is most depleted, approaching the $\delta^{13} \mathrm{C}$ value of the dominating vegetation (photosynthesis pathway dependent) (Cerling et al., 1991). Soil- $\mathrm{P}_{\mathrm{CO}_{2}}$, however, has a strong seasonal variation in regions with distinct seasonal changes in temperature and precipitation (Kiefer, 1990; Dyer and Brook, 1991; Hamada and Tanaka, 2001). At high latitudes/altitudes, root respiration and decomposition 
of organic matter cause soil- $\mathrm{P}_{\mathrm{CO}_{2}}$ to be high during the vegetation growth season, i.e. positive correlation with soil temperature. Hence, in limestone caves soil seepage waters originating from the time of most intense biological activity should dissolve more $\mathrm{CaCO}_{3}$. This has, for instance, been observed in northwestern Sweden where stalactite dripwater reached the highest $\mathrm{Ca}^{2+}$ saturation levels during summer and autumn (Sundqvist et al., 2007b). In addition, the soil$\mathrm{P}_{\mathrm{CO}_{2}}$ will be lowered by heavy and/or frequent rainfalls or by prolonged cool (reduced activity) and wet (increased infiltration) spells (Rightmire, 1978).

According to the literature above, the most depleted $\delta^{13} \mathrm{C}_{\mathrm{c}}$ values should originate from conditions with high soil$\mathrm{P}_{\mathrm{CO}_{2}}$ /high soil-T. Interpreting the isotopic shifts in FM3 (depleted-enriched-depleted) during the last 1000 years (inset, Fig. 3d) as being inversely correlated to soil- $\mathrm{P}_{\mathrm{CO}_{2}}$ suggests that a change from relatively mild/humid, to cool/wet, and returning to mild/humid, took place. Linge et al. (2009) demonstrated that the most depleted $\delta^{13} \mathrm{C}_{\mathrm{c}}$ values correlate with the thickest annual bands in a laminated stalagmite, suggesting that a higher rate of calcite accretion is not accompanied by forced/rapid $\mathrm{CO}_{2}$-degassing and kinetic fractionation and $\delta^{13} \mathrm{C}_{\mathrm{c}}$ enrichment of when $\mathrm{P}_{\mathrm{CO}_{2}}$ is high. Although the relationship between drip rates, $\mathrm{P}_{\mathrm{CO}_{2}}$, and degree of degassing is complex, the very slow drip rates observed in the FM gallery (Hansen, 2001) might partially cause the enriched $\delta^{13} \mathrm{C}_{\mathrm{c}}$-values. Under conditions approaching $100 \%$ relative humidity, however, this should not affect the $\delta^{18} \mathrm{O}_{\mathrm{c}}$ values.

\subsection{Stable oxygen isotope patterns for the last 1000 years}

The $\delta^{18} \mathrm{O}_{\mathrm{c}}$ pattern (inset, Fig. 3d) largely mirrors the conventional understanding of the climate development for the last millennium; warm - cold - warm. Firstly, the depleted isotope values (1000-400 yr) can be attributed to ameliorated climate conditions during the Mediaeval Warm Period (MWP) or Mediaeval Climate Anomaly (MCA) (e.g. Crowley and Lowery, 2000; Broecker, 2001, Trouet et al., 2009). Secondly, the interval of enriched isotope values (400-70 yr) coincides with the historically documented climate deterioration associated with the Little Ice Age (LIA) (e.g. Bradley and Jones, 1993; Mann et al., 1998; Nesje and Dahl, 2003). Thirdly, the most recent depleted values (last $\sim 70 \mathrm{yr}$ ) correspond with the warming following the LIA.

The change in $\delta^{18} \mathrm{O}_{\mathrm{c}}$ around $\sim \mathrm{AD} 1500-1725$ amounts to a relative enrichment of $0.6-0.8 \%$. Because the greater effect on fractionation of meteoric precipitation (e.g. $+0.59 \% /{ }^{\circ} \mathrm{C}$, Rozanski et al., 1993), and the opposing direction of fractionation during calcite precipitation $\left(-0.24 \%{ }^{\circ}{ }^{\circ} \mathrm{C}\right.$, O' $\mathrm{Neil}$ et al., 1969), an enrichment in the order of $0.6-0.8 \%$ o could in theory translate to $\mathrm{a} \sim+2^{\circ} \mathrm{C}$ warming (if $\delta^{18} \mathrm{O}_{\mathrm{c}}$ is dominated by the isotopic composition of meteoric precipitation). This contradicts all other observations of the climate transition onto the LIA. The observed trend is taken as confirmation of a net negative relationship between $\delta^{18} \mathrm{O}_{\mathrm{c}}$ and surface/cave temperature, echoing previous studies of Holocene stalagmites from Norway (Lauritzen and Lundberg, 1999; Linge et al., 2001, 2009). However, this interpretation invokes the need for a selective or amplifying mechanism responsible for enhancing the apparent dominance of $\mathrm{T}_{\text {cave }}$ on the direction of change in $\delta^{18} \mathrm{O}_{\mathrm{c}}$. This has previously been suggested to be through discrimination of isotopically light winter water during cooler phases because of surface runoff during snowmelt (Linge, 1999; Sundqvist et al., 2007a; Linge et al., 2009).

\subsection{Palaeoclimate variation inferred for the last 10000 years}

\subsubsection{Proxy interpretation of stalagmite data from Okshola}

Based on the current climate and monitoring of the cave, past deviations from the present-day conditions can be envisaged as relatively cold, mild, dry or wet. Because of the positive correspondence between $\delta^{18} \mathrm{O}_{\mathrm{c}}$ and $\delta^{13} \mathrm{C}_{\mathrm{c}}$ (Fig. 3c), and between $\delta^{18} \mathrm{O}_{\mathrm{c}}$ and growth rate, in the FM3 record, as well as the similarities to the L03 stable isotope and annual accretion records (Linge et al., 2009), we suggest that there is i) a negative correlation between cave/surface temperature and $\delta^{18} \mathrm{O}_{\mathrm{c}}$ and $\delta^{13} \mathrm{C}_{\mathrm{c}}$, ii) a positive correlation between wetness and $\delta^{13} \mathrm{C}_{\mathrm{c}}$, and iii) a positive correlation between cave/surface temperature and growth rate. The tripartite palaeoclimate interpretation is based on the timing of change in patterns and trends from FM3 and Oks82, rather than absolute values; hence terms used to describe changes in stable isotopes and growth rates are intended as relative to preceding/ succeeding conditions.

\subsubsection{Early Holocene (c. 10 380-7750 yr) - high variability}

Stalagmite formation in Okshola commenced shortly after the last marginal moraine was deposited in the valley (c. $9.3{ }^{14} \mathrm{C}$ ka BP, Andersen et al., 1981). Because cave calcite formation requires a source of soil- $\mathrm{CO}_{2}$, the early initiation of stalagmite growth indicates that biological activity was already present at this time. The nearby Preboreal marginal moraines (Fig. 1d) may thus have formed due to glacier stabilization rather than a result of climatic deterioration.

Frequent, high-amplitude shifts in $\delta^{18} \mathrm{O}_{\mathrm{c}}$, together with a longer-term trend towards depletion (Fig. 3d), suggest that the early Holocene was characterised by relatively mild conditions that were frequently interrupted by brief, cold events. This is in agreement with data from the Vøring Plateau indicating high-variability climate (Risebrobakken et al., 2003). The most prominent cold events, according to the Oks82 $\delta^{18} \mathrm{O}_{\mathrm{c}}$-record, occurred around $10270 \mathrm{yr}, 9850 \mathrm{yr}$, 
9700-9550 yr, and 8150-8000 yr. The $\delta^{13} \mathrm{C}_{\mathrm{c}}$ curve (Fig. 3d) suggests relatively humid conditions, if the initial trend towards depletion (reflecting soil stabilisation phase?) is disregarded. A thin soil cover above the cave may have caused surface percolation to be too rapid for equilibrating with soil$\mathrm{CO}_{2}$, and/or it was too thin to retain soil- $\mathrm{CO}_{2}$. A decent stalagmite growth rate indicates, however, that sufficient soil$\mathrm{CO}_{2}$ was transported to the cave.

\subsubsection{Mid-Holocene (c. 7750-4160 yr) - low variability}

Low-amplitude shifts in $\delta^{18} \mathrm{O}_{\mathrm{c}}$ (Fig. 3d) are seen for both stalagmites, and FM3 show a low-amplitude fluctuation around a steady state (or stepwise trend towards depletion), suggesting relatively mild conditions. A low-variability climate is in agreement with marine data from the Vøring Plateau (e.g. Risebrobakken et al., 2003). The enrichment trend in $\delta^{13} \mathrm{C}_{\mathrm{c}}$ seen for Oks82 (Fig. 3d) should be disregarded (slowgrowth to termination), but the low-amplitude fluctuations in $\delta^{13} \mathrm{C}_{\mathrm{c}}$ from $\mathrm{FM} 3$, together with its high growth rate (7$5.6 \mathrm{ka}$ ), indicate prolonged stable conditions. Combined, the stable isotope and growth records suggest relatively stable, mild and humid conditions.

\subsubsection{Late Holocene (c. 4160-0 yr) - high variability and shifts between two distinct modes}

High-amplitude variability in $\delta^{18} \mathrm{O}_{\mathrm{c}}$, and shifts between periods of relatively depleted and relatively enriched values (Fig. 3d), suggest a climate shifting between two semi-stable modes (or quasi-periodic). This is in agreement with proxy records from the Nordic Seas (e.g. Andersson et al., 2003; Risebrobakken et al., 2003). The most depleted $\delta^{13} \mathrm{C}_{\mathrm{c}}$ values, except for the longer enriched intervals, suggest a balanced humidity and a thick, stable soil cover above the cave. The longer enriched intervals must hence be interpreted as representing cold and wet conditions. All together, the stable isotope and growth records suggest shifts between mild-humid and cold-wet climate.

\subsection{Comparison with regional cave records}

\subsubsection{Cave records}

With the two stalagmites presented here, a total of nine Scandinavian stalagmites of comparable dating precision can potentially provide palaeoclimate proxies for parts, or most of the Holocene. Table 2 gives an overview of the presentday conditions from the caves (Fig. 1a) with stable isotope records available for comparison with the records from Okshola (Fauske). Of the available stalagmite records, FM3 is the most densely dated one. From Søylegrotta (Rana), we use SG93 (Lauritzen and Lundberg, 1999) dated by 12 TIMS U-Th analyses, SG95 (Linge et al., 2001) dated by 10 TIMS U-Th analyses, and SG92-4 (Berstad, 1998; Linge et al., 2001) dated by three TIMS U-Th analyses. From

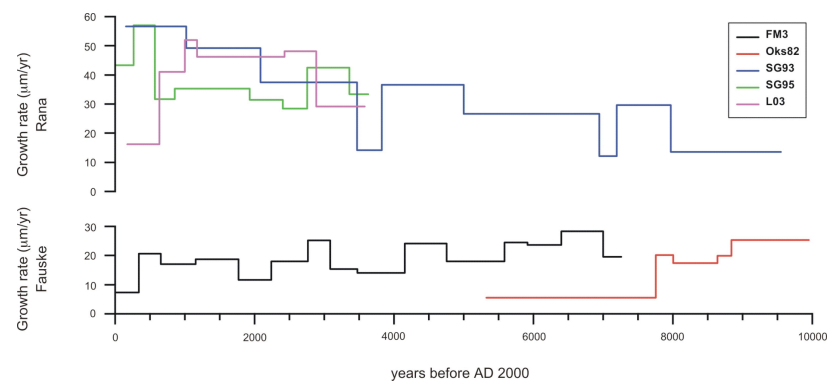

Fig. 4. Variation in growth rate with time is shown for those records dated by five or more TIMS U-Th analyses. The three upper curves (SG93, SG95, L03) show low-resolution growth rate variation from stalagmites from the Rana area, whereas the two lower curves (FM3, Oks82) show how the low-resolution growth rate has varied for the two stalagmites presented in this study (Fauske area).

Larshullet (Rana), we use L03 (Linge et al., 2009) dated by 15 TIMS U-Th analyses. From Labyrintgrottan (Lappland), we use L4 (Sundqvist et al., 2007a), dated by four TIMS U-Th analyses. From Korallgrottan (Jämtland), we use K1 and K11 (Sundqvist et al., 2007a, 2009), both records are dated by four TIMS U-Th analyses. Table 2 show that at least Lab yrintgrottan and Larshullet have mean annual surface temperatures today that is probably too low to sustain continuously active calcite deposition in the caves.

\subsubsection{Growth rates}

Variation in growth rate with time is shown in Fig. 4 for those records dated by five or more TIMS U-Th analyses. The curves from stalagmites near Rana (SG93, SG95, L03) are compared with the growth rate variations found for the two stalagmites presented in this study (FM3, Oks82). The Rana records display a general increase in growth rate towards the present, whereas the Fauske records suggest a stable or general decrease in growth rate through the Holocene. In this case, we can hypothesize that the observed difference is linked to the reformation of glaciers (e.g. Nesje, 2009), in particular to the growth of the Svartisen plateau glaciers. The formation of Svartisen must have had an impact on the regional atmospheric circulation, potentially changing the seasonal distribution of precipitation from the pattern that prevailed during the early-mid Holocene. With the few records available, however, we cannot determine whether the difference in growth rate trends is climatically induced (e.g. change in amount of annual/seasonal meteoric precipitation) or accidental. Nevertheless, the curves illustrate the constraints that come from the growth rate data. Growth rate variations with time can be a useful palaeoclimate proxy in case of annually resolved records (e.g. Baker et al., 1993; Tan et al., 2006). Closely spaced U-Th ages, on the other hand, provide low-resolution growth rates by linear interpolation between dated position, averaging out potential short-term 
Table 2. Present-day conditions at the five cave sites providing stable isotope records compared in Fig. 5.

\begin{tabular}{|c|c|c|c|c|c|c|c|c|c|}
\hline Cave & Stalagmite & $\begin{array}{l}\text { Site } \mathrm{T}_{\text {annual }} \\
(\mathrm{oC})\end{array}$ & $\begin{array}{l}\text { Cave T } \\
(\text { oC) }\end{array}$ & $\begin{array}{c}\delta^{18} \mathrm{O}_{\mathrm{c}} \\
(\% \circ \mathrm{VPDB})\end{array}$ & $\begin{array}{c}\delta^{18} \mathrm{O}_{\mathrm{W}} \\
(\% \circ \mathrm{VSMOW})\end{array}$ & $\begin{array}{l}\text { Site } P_{\text {annual }} \\
\quad(\mathrm{mm})\end{array}$ & $\begin{array}{l}\text { Drip rates } \\
(\mathrm{ml} / 24 \mathrm{~h})\end{array}$ & $\begin{array}{l}\text { Roof thickness } \\
\text { (m) }\end{array}$ & $\begin{array}{l}\text { Altitude } \\
\text { (ma.s.1.) }\end{array}$ \\
\hline Okshola $^{\mathrm{a}}\left(67^{\circ} 15^{\prime} \mathrm{N} 15^{\circ} 30^{\prime} \mathrm{E}\right)$ & FM3, Oks82 & $3.2 \pm 0.1$ & $3.2 \pm 0.1$ & -7.06 & $-10.56 \pm 0.26$ & $\sim 1050$ & $1.49 \pm 0.20$ & $20-30$ & $165-200$ \\
\hline Søylegrotta ${ }^{b}\left(66^{\circ} \mathrm{N} 13^{\circ} \mathrm{E}\right)$ & SG93, SG95 & $2.7 \pm 1.0$ & $2.8 \pm 0.3$ & -7.44 & $-10.48 \pm 2.99$ & $\sim 1450$ & $1.65 \pm 0.27$ & $\sim 100$ & $180-280$ \\
\hline Lab yrintgrottan ${ }^{\mathrm{c}}\left(66^{\circ} 3^{\prime} \mathrm{N} 14^{\circ} 40^{\prime} \mathrm{E}\right)$ & L4 & -0.5 & N/A & N/A & $-12.4^{\mathrm{f}}$ & $\sim 750$ & N/A & $10-20$ & 730 \\
\hline Korallgrottan $^{\mathrm{d}}\left(64^{\circ} 53^{\prime} \mathrm{N}^{\prime} 14^{\circ} 9^{\prime} \mathrm{E}\right)$ & $\mathrm{K} 1, \mathrm{~K} 11$ & 1.1 & $2.7 \pm 0.5$ & -8.55 & -12.4 & -850 & $0-700$ & $\sim 14$ & $540-600$ \\
\hline Larshullet $^{\mathrm{e}}\left(66^{\circ} 26^{\prime} \mathrm{N} 14^{\circ} 9^{\prime} \mathrm{E}\right)$ & L03 & 0.4 & N/A & N/A & N/A & $\sim 1600$ & N/A & $\sim 50$ & $\sim 350$ \\
\hline
\end{tabular}

Data compiled from:

${ }^{\text {a }}$ Hansen (2001), Linge et al. (this paper)

b Lauritzen and Lundberg (1999), Hansen (2001)

c Sundqvist et al. (2007a)

d Sundqvist et al. (2007a, b, 2009)

e Linge et al. (2009)

$\mathrm{f}$ (Sundqvist unpublished).

variability seen in annual records (e.g. Linge et al., 2009). The apparent timing and amplitude of a change seen in the low-resolution records depends on sample spacing. For the stalagmites included in this study, the growth rate variability should only serve as a tool for describing general trends with time - and not as records of exact timing/magnitude of change.

\subsubsection{Stable oxygen isotope time-series}

The stable oxygen isotope time-series from the five caves (Fig. 1a) are shown in Fig. 5 with a Gaussian low-pass filter ( $\sim 100 \mathrm{yr}$ running mean). All age models are based on ages corrected for initial ${ }^{230} \mathrm{Th}$, where the initial ${ }^{230} \mathrm{Th} /{ }^{232} \mathrm{Th}$ ratio is assumed to be 1.5 in the works of Berstad et al. (1998), Lauritzen and Lundberg (1999), Linge et al. (2001, 2009), whereas Sundqvist et al. (2007a, 2009) have assumed an initial ${ }^{230} \mathrm{Th} /{ }^{232} \mathrm{Th}$ ratio of 1.7 . All the records are originally interpreted to have a negative relationship between $\delta^{18} \mathrm{O}_{\mathrm{c}}$ and temperature, except K11 where Sundqvist discuss a shift from positive to negative.

Records from Fauske (165-200 ma.s.1.) display $\delta^{18} \mathrm{O}_{\mathrm{c}}$ values between -6 and $-7.5 \%$, records from Rana (180350 ma.s.l.) display values between -6.5 and $-8 \%$, whereas records from Jämtland and Lappland (540700 ma.s.1.) plot between -8.5 and $-10 \%$ (Fig. 5). This is in agreement with the altitudinal/geographical distribution of the caves.

Four records (L4, K1, SG92-4, Oks82) stopped growing before about 4500 years ago (Fig. 5). The timing of both initiation and termination of growth may be arbitrary and related to changes in local conditions. However, observations of prolonged reduced growth rate (Oks82), formation of a corrosional drip-pit (SG92-4, Berstad, 1998), and abrupt termination of growth (K1, Sundqvist et al., 2007a), suggest that a regional change caused lesser robust "water seepagecalcite precipitation" systems to break down between 6000 and $5000 \mathrm{yr}$. An intensification of extreme weather events (riverfloods, snow avalanches, colluvial events) marks the mid- to late Holocene transition (Nesje, personal communication). Such intensification would have lead to increased surface instability and hence affected the cave percolation systems. For instance, new percolation routes and locations for stalagmite deposition could have been created, and preexisting routes and locations could have experienced changes of variable degree, with a potentially strong impact on drip rates at individual drip sites. This, or local conditions, may have been responsible for three of the stalagmites, and the stalactites in Okshola, not forming until about 4000 years ago (Fig. 5).

From the filtered data, the greatest full-record amplitude $(>1.2 \%)$ is seen for the three Norwegian stalagmites (SG93, Oks82, FM3, Fig. 5) where growth began prior to $7000 \mathrm{yr}$ ago, but is also high for the youngest one from Sweden (K11). Short-term amplitudes of $0.2-0.5 \%$ are common for all records, whereas events of amplitudes $>0.7 \%$ are rare, but seen in SG93, Oks82, L4 and K11 (Fig. 5). Note that the apparent low-amplitude nature of SG95 is due to each data point being an average of two measurements (parallel series, Linge et al., 2001). Without improved age control and data analysis, we cannot really discern between the large and small amplitude variations, e.g. whether the full record amplitude reflect isotopic composition of the source water or the surface, and whether the smaller amplitude fluctuations relates to cave temperature variations, or to the isotopic composition of the dripwater.

Peaks and troughs correspond well for SG93 and SG924 between 8000 and 5000 yr (Fig. 5). Good correspondence is also seen for FM3 and Oks 82 between 8000 and $5200 \mathrm{yr}$, despite their differences in absolute values. There is also an apparent high degree of similarity between SG93, FM3 and K11 between 3200 and $500 \mathrm{yr}$, although the timing of individual changes disagrees. The differences in amplitude for many of the corresponding peaks and troughs in the $\delta^{18} \mathrm{O}_{\mathrm{c}}$ 


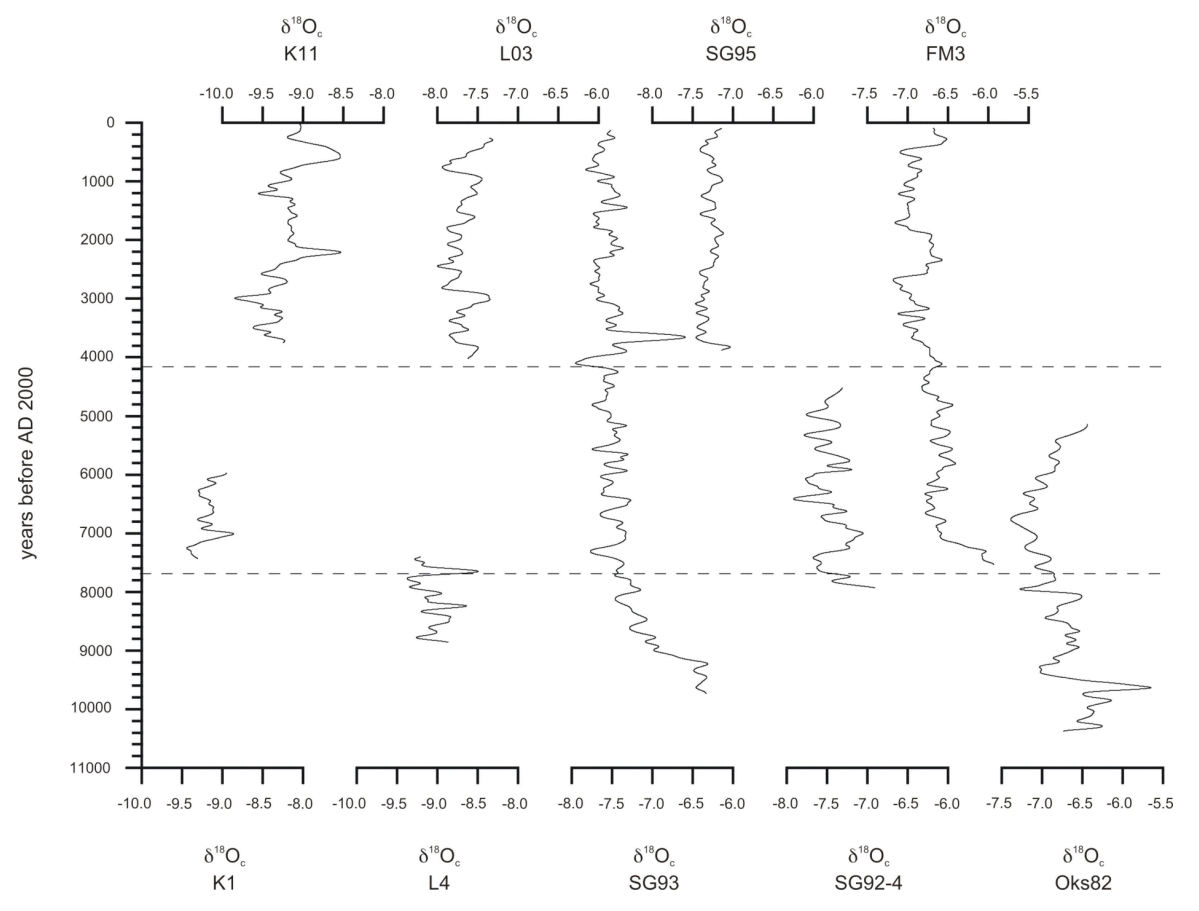

Fig. 5. Holocene stable oxygen isotope records from stalagmites between $64^{\circ}$ and $67^{\circ}$ N. See Fig. 1a for locations. FM 3 and Oks82 (Okshola, Fauske) are presented in this study. SG93 (Lauritzen and Lundberg, 1999), SG95 (Linge et al., 2001), SG92-4 (Berstad, 1998) are all from Søylegrotta (Rana). L03 (Linge et al., 2009) is from Larshullet (Rana). K11 (Sundqvist et al., 2009) and K1 (Sundqvist et al., 2007a) are from Korallgrottan, whereas L4 (Sundqvist et al., 2007a) is from Lab yrintgrottan. A Gaussian low-pass filter ( $\sim 100 \mathrm{yr}$ running mean) has been used to smooth the records.

time-series make regional correlations uncertain, illustrating that age models should be improved and/or data should be normalised before correlating events.

Only two records (FM3, SG93) cover most of the Holocene period, and these $\delta^{18} \mathrm{O}_{\mathrm{c}}$ time-series can be interpreted as displaying a long-term trend towards depletion (Fig. 5). Part of this trend can be attributed i) the change in SMOW during the early Holocene (sea water more enriched in ${ }^{18} \mathrm{O}$ than in late Holocene), and ii) a gradual SST cooling from about $6 \mathrm{ka}$, as shown by SST reconstructions based on $\mathrm{U}_{37}^{\mathrm{K}}$ from the Vøring Plateau (Calvo et al., 2002). A cooling of the source for meteoric precipitation at the coast might cause a depletion of ${ }^{18} \mathrm{O}$ in the meteoric precipitation reaching the cave sites.

The insolation at the Northern Hemisphere during the early Holocene resulted in a positive thermal anomaly during summer and a negative thermal anomaly during winter (e.g. Beer and van Geel, 2008; Crucifix, 2008), however, our stable oxygen records do not show a distinct Holocene thermal optimum (Fig. 5). The warmer temperatures experienced at the surface during summer might be counteracted by somewhat cooler conditions during winter. If the annual mean surface temperature (= cave temperature) actually was higher during the Holocene thermal optimum, the depletion of meteoric precipitation should provide isotopically heav- ier water to the caves, whereas the higher cave temp would calcite to be relatively depleted.

All records covering (parts of) the last 1000 years (Fig. 5) appear to display a depletion-enrichment-depletion pattern (cf. inset Fig. 3d) commonly interpreted as reflecting the conventional view on climate development for the last millennium, i.e. the MCA, LIA, to present climate transition. Despite the pattern similarities, the timings of change in the individual records are asynchronous, but then most age models are of low-resolution in this interval. Moreover, the observed $\delta^{18} \mathrm{O}_{\mathrm{c}}$-trend for the last c. 1000 years (inset, Fig. 3d) is commonly taken as a confirmation of a negative relationship between $\delta^{18} \mathrm{O}_{\mathrm{c}}$ and surface/cave temperature (e.g. Lauritzen and Lundberg, 1999; Linge et al., 2001, 2009). In addition, the amplitude of change in this interval suggests that the apparent dominance of $\mathrm{T}_{\text {cave }}$ on the direction of change in $\delta^{18} \mathrm{O}_{\mathrm{c}}$ must be attributed a selective or amplifying mechanism, such as discrimination of isotopically light winter water through surface runoff during snowmelt during cooler phases (Linge, 1999, 2009; Sundqvist et al., 2007a). An alternative interpretation of $\delta^{18} \mathrm{O}_{\mathrm{c}}$ from Scandinavian stalagmite records is that it primarily reflect changes in the $\delta^{18} \mathrm{O}$ of the local annual average meteoric precipitation (Hammarlund and Edwards, 2008), only modified by the temperaturedependent fractionation between water and calcite. This 
would imply that calcite precipitated during cooler intervals should be more depleted in ${ }^{18} \mathrm{O}$ than during milder intervals. The weak chronological control in the last 1000-year part of the records, illustrated by their pattern similarities but highly variable timing (Fig. 5), might well allow such an interpretation. Nevertheless, it contradicts the inverse relationship between $\delta^{18} \mathrm{O}_{\mathrm{c}}$ and annual growth rate seen from the L03 stalagmite (Linge et al., 2009) from Rana, as it is unlikely that climate amelioration should inhibit stalagmite growth. The inverse relationship between $\delta^{18} \mathrm{O}_{\mathrm{c}}$ and growth rate is also suggested from the low-resolution growth rate curves in Fig. 4, suggesting that this relationship is common for stalagmites in northern Scandinavia.

\section{Conclusions}

Stalagmites can record environmental and climate changes through variations in their growth rate and stable isotope composition, and can therefore provide valuable terrestrial proxy archives. In the Okshola cave near Fauske (northern Norway) stalagmite formation began at about $10.4 \mathrm{ka}$, soon after the valley was deglaciated. Past monitoring of the cave and surface has revealed stable modern conditions with uniform drip rates, relative humidity and temperature. Stable isotope records from two stalagmites provide time-series spanning from c. $10380 \mathrm{yr}$ to AD 1997; a banded, multicoloured stalagmite (Oks82) was formed between $10380 \mathrm{yr}$ and $5050 \mathrm{yr}$, whereas a pristine, white stalagmite (FM3) covers the period from $\sim 7500 \mathrm{yr}$ to the present. The $\delta^{18} \mathrm{O}_{\mathrm{c}}$, $\delta^{13} \mathrm{C}_{\mathrm{c}}$, and growth rate records are interpreted as showing i) a negative correlation between cave/surface temperature and $\delta^{18} \mathrm{O}_{\mathrm{c}}$, ii) a positive correlation between wetness and $\delta^{13} \mathrm{C}_{\mathrm{c}}$, and iii) a positive correlation between cave/surface temperature and growth rate. The data from Okshola show that the Holocene was characterised by high-variability climate in the early part, low-variability climate in the middle part, and high-variability and shifts between two distinct modes in the late part.

Data from the two stalagmites from Okshola are compared with data available from seven other stalagmites. The $\delta^{18} \mathrm{O}_{\mathrm{c}}$ time-series show a distinct geographical distribution of absolute values. Full-record amplitude fluctuations $(<2 \%)$ and short-term amplitude variation $(<0.7 \%$ ) form patterns that can be correlated between the records, although the exact timing and amplitude may be uncertain. A depletionenrichment-depletion pattern seen from stalagmites active during the last 1000 years is commonly interpreted as reflecting the conventional view on climate development for the last millennium, i.e. the MCA-LIA-present climate transition. None of the stalagmite $\delta^{18} \mathrm{O}_{\mathrm{c}}$ records show convincing evidence of a Holocene thermal optimum, supporting that they are influenced by annual mean temperature (cave temperature) rather than seasonal temperature. The comparison of the data from FM3 and Oks82 with other Scandinavian stalagmite records shows that although similar patterns and amplitudes of change can be correlated between the records, the main challenges for utilising high-latitude stalagmites as palaeoclimate archives are i) the accuracy of the age models, ii) the ambiguity of the proxy signals, and iii) calibration with monitoring data.

Acknowledgements. The Research Council of Norway provided financial support through NFR grants $110687 / 420$ and 122226/720. We thank Rune Sørås and Odd Hansen for stable isotope mass spectrometer operation. Joyce Lundberg is thanked for supervising the initial TIMS U-Th analysis of FM3, and for comments on its stable isotope time-series. Finalisation of the manuscript was motivated by the workshop on Holocene climate variability over Scandinavia, hosted by the Bert Bolin Centre for Climate Research, Stockholm University, in April 2008. The manuscript benefited from comments by Atle Nesje, Ian J. Fairchild, and Christoph Spötl. This is publication No. 253 from the Bjerknes Centre for Climate Research.

Edited by: K. Holmgren

\section{References}

Andersen, B. G.: Glacial geology of Northern Nordland, North Norway, Norg. Geol. Unders. B., 320, 1-74, 1975.

Andersen, B. G., Bøen, F., Nydal, R., Rasmussen, A., and Vallevik, P. N.: Radiocarbon dates of marginal moraines in Nordland, North Norway, Geogr. Ann. A, 63, 155-160, 1981.

Andersson, C., Risebrobakken, B., Jansen, E., and Dahl, S. O.: Late Holocene surface ocean conditions of the Norwegian Sea (Vøring Plateau), Paleoceanography, 18, 1044, doi:10.1029/2001PA000654, 2003.

Atkinson, T. C.: Growth mechanisms of speleothems in Castleguard Cave, Columbia Icefields, Alberta, Canada, Arctic Alpine Res., 15, 523-536, 1983.

Aune, B.: Kartblad årstider og vekstsesong (Map "Seasons of the year and growth season") 1:7 mill in: Nasjonalatlas for Norge, Tema 3.2 Klima (National Atlas of Norway, Theme 3.2 Climate), edited by: Statens kartverk, 64, 1993.

Baker, A., Smart, P. L., Edwards, R. L., and Richards, D. A.: Annual growth banding in a cave stalagmite, Nature, 364, 518-520, 1993.

Baker, A., Genty, D., Dreybrodt, W., Barnes, W. L., Mockler, N. J., and Grapes, J.: Testing theoretically predicted stalagmite growth rate with recent annually laminated samples: implications for past stalagmite deposition, Geochim. Cosmochim. Ac., 62, 393404, 1998.

Baldini, J. U. L., McDermott, F., Baker, A., Baldini, L. M., Mattey, D. P., and Railsback, L. B.: Biomass effects on stalagmite growth rate and isotope ratios: A 20th century analogue from Wiltshire, England, Earth Planet. Sc. Lett., 240, 486-494, 2005.

Baldini, J. U. L., Baldini, L. M., McDermott, F., and Clipson, N.: Carbon dioxide sources, sinks, and spatial variability in shallow temperate zone caves: evidence from Ballynamintra Cave, Ireland, J. Cave. Karst. Stud., 68, 4-11, 2006.

Baldini, J. U. L., McDermott, F., Hoffmann, D. L., Richards, D. A., and Clipson, N.: Very high-frequency and seasonal cave atmosphere $\mathrm{P}_{\mathrm{CO}_{2}}$ variability: Implications for stalagmite growth 
and oxygen isotope-based paleoclimate records, Earth Planet. Sc. Lett., 272, 118-129, 2008.

Beer, J. and van Geel, B.: Holocene climate change and the evidence for solar and other forcings, in: Natural climate variability and global warming - A Holocene perspective, edited by: Battarbee, R. W. and Binney, H. A., Wiley-Blackwell, 138-162, 2008.

Berstad, I.: Uranseriedatering og stabilisotopanalyse av speleothemer fra Søylegrotta, Mo i Rana, Cand. scient. thesis, University of Bergen, Bergen, 122 pp., 1998.

Bradley, R. S. and Jones, P. D.: "Little Ice Age" summer temperature variations: their nature and relevance to recent global warming trends, Holocene, 3, 367-376, 1993.

Broecker, W. S.: Was the Medieval Warm Period global?, Science, 291, 1497-1499, 2001.

Calvo, E., Grimalt, J., and Jansen, E.: High resolution $\mathrm{U}_{37}^{K}$ sea surface temperature reconstruction in the Norwegian Sea during the Holocene, Quaternary Sci. Rev., 21, 1385-1394, 2002.

Cerling, T. E., Solomon, D. K., Quade, J., and Bowman, J. R.: On the isotopic composition of carbon in soil carbon dioxide, Geochim. Cosmochim. Ac., 55, 3403-3405, 1991.

Crowley, T. J. and Lowery, T. S.: How warm was the Medieval Warm Period?, Ambio, 29, 51-54, 2000.

Crucifix, M.: Modelling the climate of the Holocene, in: Global warming and natural climate variability - a Holocene perspective, edited by: Battarbee, R. W. and Binney, H. A., Wiley-Blackwell, 98-122, 2008.

Drange, H., Dokken, T., Furevik, T., Gerdes, R., and Berger, W.: The Nordic Seas. An integrated perspective. Oceanography, Climatology, Biogeochemistry, and Modeling, American Geophysical Union, Washington DC, 366 pp., 2005.

Dreybrodt, W.: Chemical kinetics, speleothem growth and climate, Boreas, 28, 347-356, 1999.

Dyer, J. M. and Brook, G. A.: Spatial and temporal variations in temperate forest soil carbon dioxide during the non-growing season, Earth Surf. Processes, 16, 411-426, 1991.

Einevoll, S. and Lauritzen, S.-E.: Calibration of stable isotope and temperature signal in the percolation zone of a sub-arctic cave, Northern Norway, Cave and Karst Science, 21, p. 9, 1994.

Fairchild, I. J., Smith, C. L., Baker, A., Fuller, L., Spötl, C., Mattey, D., McDermott, F., and E. I. M. F.: Modification and preservation of environmental signals in speleothems, Earth-Sci. Rev., 75, 105-153, 2006.

Fantidis, J. and Ehhalt, D. H.: Variations in the carbon and oxygen isotopic composition in stalamites and stalactites: evidence of non-equilibrium isotopic fractionation, Earth Planet. Sc. Lett., 10, 136-144, 1970.

Gascoyne, M.: Palaeoclimate determination from cave calcite deposits, Quaternary Sci. Rev., 11, 609-632, 1992.

Genty, D. and Quinif, Y.: Annually laminated sequences in the internal structure of some Belgian stalagmites - importance for paleoclimatology, J. Sediment. Res., 66, 275-288, 1996.

Genty, D., Baker, A., and Vokal, B.: Intra- and inter-annual growth rate of modern stalagmites, Chem. Geol., 176, 191-212, 2001.

Goldstein, S. J. and Stirling, C. H.: Techniques for measuring uranium-series nuclides: 1992-2002, Rev. Mineral. Geochem., 52, 23-57, 2003.

Hamada, Y. and Tanaka, T.: Dynamics of carbon dioxide in soil profiles based on long-term field observations, Hydrol. Process., $15,1829-1845,2001$.
Hammarlund, D. and Edwards, T. W. D.: Stable isotope variations in stalagmites from northwestern Sweden document changes in temperature and vegetation during the early Holocene: a comment on Sundqvist et al. 2007a, Holocene, 18, 1007-1008, 2008.

Hansen, J. K.: Mikroklimatologi i to karsthuler i Rana og Fauske: måleserier med henblikk på paleoklimatologisk kalibrering, MS thesis, University of Bergen, Bergen, 135 pp., 2001.

Hellstrom, J.: U-Th dating of speleothems with high initial ${ }^{230} \mathrm{Th}$ using stratigraphical constraint, Quat. Geochonol., 1, 289-295, 2006.

Hendy, C. H.: The isotopic geochemistry of speleothems -1 . The calculation of the effects of different modes of formation on the isotopic composition of speleothems and their applicability as palaeoclimatic indicators, Geochim. Cosmochim. Ac., 35, 801824, 1971.

Hesterberg, R. and Siegenthaler, U.: Production and stable isotopic composition of $\mathrm{CO}_{2}$ in a soil near Bern, Switzerland, Tellus, 43B, 197-205, 1991.

Hurrell, J. W., Kushnir, Y., Ottersen, G., and Visbeck, M.: An overview of the North Atlantic Oscillation, Geoph. Monog. Series, 134, 1-35, 2003.

Ivanovich, M. and Harmon, R. S.: Uranium-series disequilibrium: applications to earth, marine, and environmental sciences, Clarendon Press, Oxford, 910 pp., 1992.

Kaufmann, G. and Dreybrodt, W.: Stalagmite growth and palaeoclimate: an inverse approach, Earth Planet. Sc. Lett., 224, 529$545,2004$.

Kiefer, R. H.: Soil carbon dioxide concentrations and climate in a humid subtropical environment, Prof. Geogr., 42, 182-194, 1990.

Lachniet, M. S.: Climatic and environmental controls on speleothem oxygen-isotope values, Quaternary Sci. Rev., 5-6, 412-432, 2009.

Lauritzen, S.-E., Løvlie, R., Moe, D., and Østbye, E.: Paleoclimate deduced from a multidisciplinary study of a half-million-yearold stalagmite from Rana, Northern Norway, Quaternary Res., 34, 306-316, 1990.

Lauritzen, S.-E.: Uranium series dating of speleothems: a glacial chronology for Nordland; Norway, for the last $600 \mathrm{ka}$, Striae, 34, 127-133, 1991.

Lauritzen, S.-E.: High-resolution paleotemperature proxy record for the Last Interglaciation based on Norwegian speleothems, Quaternary Res., 43, 133-146, 1995.

Lauritzen, S.-E.: Karst landforms and caves of Nordland, North Norway, Guide for excursion 2 - Climate change; the karst record, Department of geology, University of Bergen, 1996.

Lauritzen, S.-E. and Lundberg, J.: Calibration of the speleothem delta function: an absolute temperature record for the Holocene in northern Norway, Holocene, 9, 659-669, 1999.

Lauritzen, S.-E.: Reconstructing Holocene climate records from speleothems, in: Global Change in the Holocene, edited by: Mackay, A., Battarbee, R., Birks, J. and Oldfield, F., Hodder Arnold, London, 242-263, 2003.

Linge, H.: Isotopic studies of some northern Norwegian speleothems and calcareous algae from Svalbard, Ph.D. thesis, University of Bergen, Bergen, 83 pp., 1999.

Linge, H., Lauritzen, S.-E., Lundberg, J., and Berstad, I. M.: Stable isotope stratigraphy of Holocene speleothems: examples from a cave system in Rana, northern Norway, Palaeogeogr. Palaeocl., 
167, 209-224, 2001.

Linge, H., Baker, A., Dahl, C. A., and Lauritzen, S.-E.: Variability in luminescent lamination and initial ${ }^{230} \mathrm{Th} /{ }^{232} \mathrm{Th}$ activity ratios in a late Holocene stalagmite from northern Norway, Quat. Geochronol., 4, 181-192, 2009.

Mangini, A., Spötl, C., and Verdes, P.: Reconstruction of temperature in the Central Alps during the past $2000 \mathrm{yr}$ from a d ${ }^{18} \mathrm{O}$ stalagmite record, Earth Planet. Sc. Lett., 235, 741-751, 2005.

Mann, M. E., Bradley, R. S., and Hughes, M. K.: Global-scale temperature patterns and climate forcing over the past six centuries, Nature, 392, 779-787, 1998.

McDermott, F.: Palaeo-climate reconstruction from stable isotope variations in speleothems: a review, Quaternary Sci. Rev., 23, 901-918, 2004.

Mickler, P. J., Stern, L. A., and Banner, J. L.: Large kinetic isotope effects in modern speleothems, Geol. Soc. Am. Bull., 118, 6581, 2006.

Nesje, A. and Dahl, S.-O.: The "Little Ice Age" - only temperature?, Holocene, 13, 139-145, 2003.

Nesje, A.: Latest Pleistocene and Holocene alpine glacier fluctuations in Scandinavia, Quaternary Sci. Rev., 28, 2119-2136, 2009.

O’Neil, J. R., Clayton, R. N., and Mayeda, T. K.: Oxygen isotope fractionation in divalent metal carbonates, J. Chem. Phys., 51, 5547-5558, 1969.

Richards, D. A. and Dorale, J. A.: Uranium-series chronology and environmental applications of speleothems, Rev. Mineral. Geochem., 52, 407-460, 2003.

Rightmire, C. T.: Seasonal variation in $\mathrm{P}_{\mathrm{CO}_{2}}$ and ${ }^{13} \mathrm{C}$ content of soil atmosphere, Water Resour. Res., 14, 691-692, 1978.

Risebrobakken, B., Jansen, E., Andersson, C., Mjelde, E., and Hevrøy, K.: A high-resolution study of Holocene paleoclimatic and paleoceanographic changes in the Nordic Seas, Paleoceanography, 18(1), 1017, doi:10.1029/2002PA000764, 2003.
Rozanski, K., Araguás-Araguás, L., and Gonfiantini, R.: Isotopic patterns in modern global precipitation, Geoph. Monog. Series, 78, 1-36, 1993.

Spötl, C. and Mangini, A.: Speleothems and paleoglaciers, Earth Planet. Sc. Lett., 254, 323-331, 2007.

Sundqvist, H. S., Holmgren, K., and Lauritzen, S.-E.: Stable isotope variations in stalagmites from northwestern Sweden document climate and environmental changes during the early Holocene, Holocene, 17, 259-267, 2007a.

Sundqvist, H. S., Seibert, J., and Holmgren, K.: Understanding conditions behind speleothem formation in Korallgrottan, northwestern Sweden, J. Hydrol., 347, 13-22, 2007b.

Sundqvist, H. S., Holmgren, K., Moberg, A., Spötl, C., and Mangini, A.: Stable isotopes in a stalagmite NW Sweden document environmental changes over the past 4000 years, Boreas, doi: 10.1111/j.1502-3885.2009.00099.x, 2009.

Tan, M., Baker, A., Genty, D., Smith, C., Esper, J., and Cai, B.: Applications of stalagmite laminae to paleoclimate reconstructions: Comparison with dendrochronology/climatology, Quaternary Sci. Rev., 25, 2103-2117, 2006.

Trouet, V., Esper, J., Graham, N. E., Baker, A., Scourse, J. D., and Frank, D. C.: Persistent positive North Atlantic Oscillation mode dominated the Medieval Climate Anomaly, Science, 324, 78-80, 2009.

Usdowski, E. and Hoefs, J.: Kinetic ${ }^{13} \mathrm{C} /{ }^{12} \mathrm{C}$ and ${ }^{18} \mathrm{O} /{ }^{16} \mathrm{O}$ effects upon dissolution and outgassing of $\mathrm{CO}_{2}$ in the system $\mathrm{CO}_{2}-\mathrm{H}_{2} \mathrm{O}$, Chem. Geol., 80, 109-118, 1990.

van Calsteren, P. and Thomas, L.: Uranium-series dating applications in natural environmental science, Earth-Sci. Rev., 75, 155$175,2006$.

Vollweiler, N., Scholz, D., Mühlinghaus, C., Mangini, A., and Spötl, C.: A precisely dated climate record for the last $9 \mathrm{k} \mathrm{yr}$ for three high alpine stalagmites, Spannagel Cave, Austria, Geophys. Res. Lett., 33, L20703, doi:10.1029/2006GL027662, 2006. 